\title{
ARABIC LEXICOGRAPHY AND EUROPEAN AESTHETICS: THE ORIGIN OF FANN
}

This article deals with the word fann, used today for "art" in Modern Standard Arabic. This word has a long history in almost all the languages that stood in mutual interplay with Arabic, particularly Persian and Ottoman Turkish. Since the late nineteenth century, it has been used in Arabic as the direct translation for the nineteenth-century Western European concept of "art." But why was this word chosen to denote the phenomenon of art?

To try to answer this question, I will first explore the terms fann and $\sin ^{\prime} a$ (craft, practical knowledge, skill) in the Arabic lexicographical tradition. Second, I attempt to analyze the non-lexicographical usage of fann and to sketch a theory of how this word acquired its "artistic" meaning via metonymy, using in particular writings on poetry, with an outlook to the Ottoman Turkish word san'at. Third, I focus on the nineteenthcentury renewal of Arabic in the context of the Ottoman school system and imperial administration, as well as travelers' writings and the early Arabic press. I thus show that the choice of fann to denote the nineteenthcentury European concept of art was not a coincidence: the first to employ it in this sense in Arabic was the famous nineteenth-century Egyptian writer and educator Rifa'a Rafi' al-Tahtawi, who translated not only the concept but also its place in the contemporary Western European hierarchy of human activities. However, the general canonization and development of the use of this word was a longer and less smooth process.

Here I use a very special sense of the English word "art." In the English language, this word was until recently understood as referring to the "fine arts" and rarely included theater or music. ${ }^{1}$ But in my usage, "art" encompasses all genres, along with all its institutions and attending political and economic implications in the nineteenth century; thus, it is by definition associated with the public sphere. ${ }^{2}$ I do not want to essentialize, monopolize, or restrict the word "art," other than to facilitate my argumentation here. Therefore, this is not to say that apart from this special, historicized concept of "art" there were no creative traditions in other parts of the world-or even in Europe itself-or that previously there were no theories of beauty or images. In fact, one of the arguments of this essay is that one can detect in Arabic a concept of "art," a creative production that implies "art" as a specialized knowledge.

In connection with this last remark, I also want to emphasize that the terms "Arab" or "Arabic" (or even "Europe") are not used here in an essentializing way: "Arabic" simply refers to a written language and scientific lingua franca shared by numerous peoples of different origins. This is a study in the history of ideas in Arabic, based on written sources.

There are, nonetheless, three implicit methodological limitations. First, the selection of texts was arbitrary and their scope limited. Second, although I tried to be sensitive to actual creative practices, material artefacts, and the related art-historical literature, I had to be rather restrictive in this respect as well. Third, my expertise is limited to texts in Arabic-which is not meant to imply that these belong only to "Arabic literature."

Ottoman Turkish and Persian references are included, but I openly confess that I do not aim at any general (and in my eyes, misleading) statements about the concept of art in "Islamic culture" or in the "world of Islam." My final conclusions are restricted to Arabic texts and are about the word used in that language for the nineteenth-century (Western European) concept of art. Nonetheless, the mutual interplay of these three languages (not to mention Spanish, Italian [in earlier cen- 
turies], and French [in later ones]) is considered to be crucial. Yet, it is the nature of such endeavors that I cannot provide full and final answers. I am interested here in how the nineteenth-century concept of art, which was actually quite new or in-the-making in Western Europe, was translated and understood in Arabic, even as it spread, and was received, negotiated, and reinvented in nearly all languages, from Hungarian to Indonesian, in the nineteenth and early twentieth centuries.

This question arises from the acknowledgment that from the late nineteenth-century era of colonialism until today, Western European traditions of art have been present in the creative output of Arab territories and countries, which frequently mix traditional patterns (folk or religious) with European novelties such as Cubism. One might consider, for instance, the socalled hurüfì movement, which uses Arabic letters (sing. harf, pl. hurūf) in an abstract way to convey not literary but artistic meanings, through various modifications and arrangements. ${ }^{3}$ In Wikipedia's entry in Arabic on art, fann is defined as nitāj ibdā' $\bar{\imath}$ insāni (a creative human product), in accordance with the globalized concept of art. $^{4}$

With respect to the Arab reception of new artistic practices, Silvia Naef makes a distinction between periods of adoption (1900-1945) and adaptation (1945-60), to which one can today add the reinvention of traditions, hybrid works, and Arab political art. ${ }^{5}$ Contemporary Arab artistic production is so charged with questions of identity, language, and religion that it poses in itself the troublesome question of what and whose traditions will be used by the not necessarily secular artist, who does not necessarily live in the Middle East. ${ }^{6}$ By way of comparison, Wendy M. K. Shaw theorizes the nineteenth-century Ottoman reception of European painting as the "Western modality of art" entering Ottoman visual culture, for which "artists had to forge meanings." 7

For approaches to beauty, works of art, and artistic crafts before the nineteenth century, there are different texts from different Islamic "cultures" and ages ranging from the Koran, ${ }^{8}$ through commentaries on philosophy and logic, ${ }^{9}$ to the great synthesis of Ottoman literature on painting, which also continued and translated Persian traditions. ${ }^{10}$ Today, scholars of these relatively well-known texts and works often write about Islamic "aesthetics" or the "history of Islamic arts," but these branches of knowledge (i.e., aesthetics and art history) did not exist in Arabic, Ottoman Turkish, or Persian until the twentieth century. ${ }^{11}$ Yet, following Doris Behrens-Abouseif, this absence does not imply that there were no perceptions of creative or beautiful works as individual and non-religious artefacts ${ }^{12}$ or, as Gülru Necipoğlu argues, that there were no formulations of the creative genius. ${ }^{13}$

It must also be stated that there is a difference between the concept $(s)$ of art and the word $(s)$ used to denote it. To decide whether it is possible for a concept to exist without a proper word to designate it or whether an idea may remain the same while the word used for it changes is the task of philosophers and cognitive linguists. Still, it is imperative to underline that when I ask why a certain word is used for a certain concept in Arabic, whether in the nineteenth century or today, I do not aim to determine whether the concept existed previously. Even so, "art" in its nineteenth-century form was a quite recent invention in Western Europe. ${ }^{14}$

Thus, if one acknowledges that the use of fann for art in Arabic was a new linguistic practice, ${ }^{15}$ too, then what information can be provided by the Arabic lexicographical tradition? Is this new practice in fact a continuation of an already given linguistic-cultural-aesthetic understanding, or a clear result of linguistic renewal?

I would like to emphasize that since-as will be seen - the preliminary meanings of fann were "kind" and "branch," it follows naturally that if today one wants to render that term into English, according to the context it will be translated as "chapter," "branch," "genre," "art," or even "race." Fann is a case par excellence of metonymy. The underlying reason for this is that not only is the basic semantic field of the word fann an abstract and general theorization about quantity and diversity but its usage possesses a certain quality of linguistic freedom such that the exact meaning of fann will be clear only from the context.

In English, "art" (from the Old French) is usually understood as having evolved from the Greek techne and Latin ars, that is, the "making" of something artificial. ${ }^{16}$ We know quite well that the Arabic word for the Greek technē was șinā $a$ in Neo-Platonic literature. ${ }^{17}$ 
Although it seems self-evident, it is worth asking why fann rather than șinā'a was ultimately chosen to designate "art" in the nineteenth century.

\section{LEXICOGRAPHICAL MEANINGS OF FANN AND ȘINA'A}

\section{The entries on fann (f- $\mathrm{n}-\mathrm{n}$ and variations thereof)}

It is necessary to consider the entries on fann $(f-n-n$ or variations) in various Arabic reference works (table 1). ${ }^{18}$ The Kitāb al-'Ayn (The Book of [the letter] 'Ayn), considered to be the first Arabic dictionary, was compiled by al-Khalil b. Ahmad (d. ca. 805) and al-Layth b. al-Muzaffar (d. before 815$).{ }^{19}$ In this work, fann means "condition" (hăl) and its plural, funūn, means "kinds" (i.e., sorts of things); it has a second plural form: afnān. The verb fannana in the second stem is used in connection with speech: "a man yufannin the speech means: he branched off from one kind [of mode of speech] after another (i.e., diversified his speech, ishtaqqa)." Here one also finds the noun fanan, which means "the branch [of a tree], and its plural is afnān." Thus, the meaning of fann as a noun is: kind, sort, species, condition. Kalām, here "speech," the verbal expression of thoughts, is associated with the second stem. It is worth noting that the plural form afnān corresponds to two singular forms and thus can mean equally "kinds" and "branches."20

The dictionary of Abu Mansur al-Azhari (d. 981), known as Tahdhìb al-lugha (Correction of the Language), is in part a continuation of the 'Ayn, with extensive additions. ${ }^{21}$ Here is found the first reference to the Koranic usage of fann: "Ikrima" 22 said about the words of God, the Mighty and the Great: 'would you deny? having [spreading] branches [afnān]' (55:48). He ['Ikrima] said: the shadow of the branches (aghșann) is on the walls. ${ }^{23} \mathrm{Abu}$ 'l-Haytham ${ }^{24}$ said: someone explained afnān as 'having branches' (aghșān) and another person explained it as 'having leaves' (alwān)." Then, on the authority of Abu 'l-Haytham, it is stated that according to some, if afnān means "leaves," then its singular is fann, but if it means "branches," its singular is fanan.
Al-Azhari notes that afnān is the plural of both fann and fanan. He also introduces the form afänīn (second plural of fanan) meaning "locks of hair." The plural afnān could mean: "kinds" (sing. fann), "branches" (sing. fanan), "leaves" (sing. fann), and "locks of hair" (sing. fanan). Citing Abu 'Ubayd, ${ }^{25}$ the author provides two more interesting meanings for fann: "pain/trouble" ('ana') and "driving away a camel" (tard).

Another new form appears: mifann (in tandem with mi'ann). The grammatical origin of this form is mif'al (the intensifying adjective), meaning a person who can speak with a good style and knows how to argue-one who knows funūn min al-kalām (different kinds or styles of speech). So fann, in this sense, is a kind of knowledge (of speech, or of eloquence) and it is possible that this meaning was derived from the second stem (fannana). This sense will be absorbed by or blended with the sense of "branch." Al-Azhari gives a new meaning for the mașdar of the second stem, tafnin: "a bolt of cloth." It is important to underline that the Tahdhì $b$ is crucial to the development of the later mainstream tradition because al-Azhari's data was, in many cases, simply copied. ${ }^{26}$

Sihâh (The Authentic One) was the most popular Arabic dictionary of the Middle Ages. Compiled by al-Jawhari (d. between $1003^{27}$ and 1009), it contains new material based on other traditions, at least in the case of the entry on fann. Al-Jawhari is the first to draw a clear distinction between fann (with the plural funūn) and fanan (with the plural afnān). Fann is preliminarily associated with speech, language, and knowledge. The plural afänīn here means "kinds/styles of speech" (not "locks of hair," as in the Tahdhìb). A new form, a verb in the eighth stem, appears as well-iftanna - with the active meaning "someone who presents wonders or wonderful things." 28

The plan of the much-respected dictionary Mujmal al-lugha (Summary of the Language), compiled by Ibn Faris (d. 1005), was to trace words with multiple meanings back to their basic meaning $(u s \underline{u} l) .{ }^{29}$ It is said that in contrast with previous linguists he collected not only difficult expressions of poetry, but also those words (and their meanings) that were currently "in use." 30 The author pays no attention to the definition of fann as "condition, kind" that was given in the 'Ayn. Although 
Table 1. Lexicographical meanings of fann in medieval Arabic. Nouns and verbs are classified together and only selected meanings are given.

\begin{tabular}{|l|l|l|l|l|}
\hline Author & Date & Word & Plüals & Meaning \\
\hline al-Khalil & late 8th c. /early 9th c. & $\begin{array}{l}\text { fann(a), } \\
\text { fannana }\end{array}$ & funūn, afnān & $\begin{array}{l}\text { kind, sort, species, condition, to } \\
\text { diversify the speech }\end{array}$ \\
\hline al-Khalil & late 8th c. /early 9th c. & fanan & afnān & branch \\
\hline al-Azhari & middle of 10th c. & fann(a) & funūn, afnān & $\begin{array}{l}\text { kind, leaf, to drive away a } \\
\text { camel, pain, trouble }\end{array}$ \\
\hline al-Azhari & middle of 10th c. & fanan & afnān, 2nd. pl. afänīn & branch, lock of hair \\
\hline al-Jawhari & late 10th c. & fann, iftanna & funūn & kind, branch (of speech) \\
\hline al-Jawhari & late 10th c. & fanan & afnān, 2nd. pl. afänīn & kind of speech \\
\hline Ibn Faris & late 10th c. & fann(a) & funūn & to drive away a camel, pain, \\
\hline trouble
\end{tabular}

Ibn Faris was a contemporary of al-Jawhari, he acknowledges only "driving of the camel" and "pain/trouble" as meanings of fann. At first glance, it looks as if, in the territories where he lived or in the texts that he read, the close connection between fann and speech was not known. ${ }^{31}$

The Asās al-balägha (Basis of Eloquence) of al-Zamakhshari (d. 1144) is primarily a thesaurus for rhetoric. Only the plural forms of fann (afnān and afāninn) are cited. It is important to note that we do not find in this work the expression afänin min al-kalām, literally, "kinds from the speech," but rather the abridged afānīn al-kalām, meaning "kinds of speech." In the Asās, the derivatives of fann are primarily associated with speech, discourse, and language, denoting their kinds and styles (which is perhaps not surprising in a dictionary of eloquence). Although in most of the entries al-Zamakhshari provides both the ordinary and the metaphorical usages (min al-majāz), unfortunately in the case of fann he omits the majāz. ${ }^{32}$
It is worth mentioning the Arabic bilingual dictionaries of early lexicographers. The Dìwān lughāt al-Turk (Compendium of Turkish Languages) by al-Kashgari (eleventh century) is the earliest dictionary devoted to the Turkic language(s).$^{33}$ However, as this book is rather a companion for translating and explaining Turkish vocabulary and grammar to readers of Arabic and not vice versa, we do not know how fann might have been translated into Turkish in the eleventh century. ${ }^{34}$ The Turkish tü tü was translated into Arabic as min kull jins (all kinds of things), and türlüg (different kinds) as $a n w \bar{a}{ }^{\prime}$ and $a s ̧ n a \bar{f}$ (kinds). Fann, even in the meaning of "kind," is not used in these entries. ${ }^{35}$

In the twelfth century, al-Zamakhshari prepared another work, Aqșa 'l-arab fì muqaddimat al-adab (The Utmost Desire to Present Elegant Behavior), one of the earliest Arabic-Persian dictionaries (known as the Lexicon Persicum in Orientalist scholarship), ${ }^{36}$ for the library of the Khwarezmshah Atuz (r. 1127-56). ${ }^{37} \mathrm{He}$ mentions fann among the Arabic words used for "kind, 
sort" (with the plural funūn), ${ }^{38}$ or in connection with speech: fannana al-hadith (diversified the discourse/ provided various kinds of speech). ${ }^{39}$ Al-Zamakhshari also lists fanan among the expressions used in reference to a garden, with the plural afänin meaning "branch." 40

Numerous Arabic-Turkish, Arabic-Persian, and Turkish-Persian dictionaries (and vice versa) were prepared between the thirteenth and nineteenth centuries. Though consideration of these is beyond the scope of this essay, they were, nevertheless, crucial for the development of the scientific and special vocabulary of these languages and are definitely worthy of further research.

The largest Arabic dictionary, Lisān al-'Arab (Tongue of the Arabs), by Ibn Manzur (known in the East as Ibn Mukarram, d. 1311), takes the Tahdhīb and the Muhkam (The Masterful) of Ibn Sidah as its basis; arranged in the manner of the Sihhāh (with the twelfth century grammarian Ibn Barri's annotations), it also contains the thesaurus Nihàya fì gharīb al-hadìth (The Utmost [Effort] for the Unusual [Words] of the Tradition) by Ibn alAthir, the brother of the famous historian. ${ }^{41}$ As this project incorporates and repeats most of the material on fann already discussed, I will here mention only what is new. Ibn Manzur uncritically repeats the afnān dilemma of the Tahdhi $b$-namely, whether its singular is fann (leaf), or fanan (branch). With this, the distinction (drawn by al-Jawhari) between the singular forms fann and fanan vanishes or, rather, the original ambiguity is restored. The form funün has a third meaning: if it is linked with people, it can be translated, by way of metonymy from the meaning "branch," as "races."

Here one again discerns the undoubted preeminence of the derivatives of fann that are associated with language (especially iftanna), while the term afäninn is associated with styles of speech. Ibn Manzur keeps the other rare meanings such as "locks of hair." Fannān, which today means "artist," is used thusly: "the fannān in the poetry of al-A'sha [means]: donkey, the wild one, which has various sorts of running."

Mifann (associated with humans) appears three times: first, as an adjective in reference to the man who presents wonders or miraculous things; second, as a modifier describing a well-spoken and educated man; and, finally, as an adjective (in the feminine) of a woman who did something wrong. In the Lisān, the word fann has its most surprising meaning: ghabn (cheating). ${ }^{42}$
Another synthesis is the celebrated al-Qāmūs al-muhìt (The All-Embracing Ocean, i.e., The Comprehensive Dictionary) by al-Firuzabadi (d. 1415.), a compilation of Ibn Sidah's Muhkam and al-Saghani's 'Ubāb (Torrents). ${ }^{43}$ The most interesting, and, from the point of view of this essay, revolutionary addition is tazyin, that is, "ornamentation" (though it could mean "pretense" too). Another newly occurring form is written with a kasra: finn. The genitive structure finn al-ilm indicates someone who is good in science. The root $f-n-n$ is again closely related to science and knowledge. ${ }^{44}$

The giant dictionary Tāj al-'arūs (Crown of the Bride) was compiled in Egypt in the eighteenth century by Muhammad Murtada 'l-Zabidi (d. 1791). ${ }^{45}$ The work repeats the most valuable additions of the Qāmūs, namely, tazyin, and finn in reference to science, and only adds the material found in the Lisān. ${ }^{46}$ Yet, as shall be seen below, al-Zabidi uses fann in a more interesting manner in the introduction to his work. ${ }^{47}$

The modern dictionary Muhìt al-muhìt (The AllEmbracing of the All-Embracing), which was prepared by Butrus al-Bustani (d. 1883) between 1867 and 1870, says the following with regard to fann in the meaning of "kind": "Sometimes semantic extension is applied and it is used for craft, science, and for a class of written essays" (rubbamā tuwussi'a fī-hi fa-uțliqa 'ala 'l-șinā'a wa 'l-ilm wa-'alà qism min al-maqāla). ${ }^{48}$ This remark signifies a recognition of the non-lexicographical tradition, that is, the actual, but still textual, medieval usage of fann. ${ }^{49}$

\section{The entries on șināa (ṣ-n-' and variations thereof)}

The entry for $s-n$ - $^{-}$in the Kitāb al-'Ayn starts with a Koranic allusion: "how good is the way God worked on him, he is well-made" (șun' Alläh [Koran 27:88]). AlKhalil gives the basic meanings again: al-sunnā' refers to those "who work with their hands" (alladhina ya'maluna bi-aydī-him). The mașdar of the fifth stem (tașannu') signifies "the quality of style and opinion, whose content is in opposition to its form." 50

Al-Azhari's Tahdhìb al-lugha contains an entry that would again serve as a basis for discussions of $\sin ^{-} a$ in many later dictionaries. This work supplements the meaning "something which is made" by pointing to mașna' (a dam for collecting water, building, village), 
and, most importantly for this study, șinā'a as "profession/occupation" (hirfa), cited from al-Asma i..$^{51}$

The entry in the Sihnah retains the semantic field of "working with two hands" (șanī al-yadayn). Thus, in this respect, $s-n$ - is also used in reference to built structures, such as a basin (mașna'a) or castles (mașāni $\left.{ }^{\prime}\right)$, already given in the Tahdhì $b .^{52}$

According to the correct definition of Asās al-balägha, a master (șāni' and mähir) is one who knows his profession and the way he has to work (sināati-hi wa-șan'ati-hi). Al-Zamakhshari elaborates on the meaning of mașna'a: "the Arabs use this expression also as 'someone from the mașāni" and they mean by this the people of the villages and the towns." Regarding the metaphorical usages, it is perhaps important to note that if a garment was called șanī it meant a "good" one (well-made [already in the Tahdhīb]). ${ }^{53}$

From the early bilingual dictionaries, al-Kashgari translates the Turkish terms iş (work) and uzluk (craft) into Arabic as 'amal and hirfa, respectively, but for some reason he does not use the root ș-n-'. He only renders $u z$ kişi (skillful person) into Arabic as șun' al-yad. ${ }^{54}$ In his Arabic-Persian dictionary, al-Zamakhshari presents almost all the usual derivatives of $s-n-^{-}$, starting with șan' $a$ as kār (work), etc. ${ }^{55}$ Later Arabic dictionaries do not provide any important addition to the already mentioned meanings; ${ }^{56}$ the concept of "craft/occupation" remains the central definition..$^{57}$ In the nineteenth century, al-Bustani noted in Muhit al-muhìt that:

It is said that $\sin ^{-} a$ in the professions of the ordinary people is the knowledge that is achieved by practice, like sewing and weaving, etc., which is based on repeated exercise. However, for the elite [the learned], this is the knowledge, which is bound to the quality (kayfiyya) of the work. This could mean either activities like sewing, etc., which is achieved by practice, or those like religious law, logic, grammar, or practical wisdom, which are not acquired by executing work [with hands]. They say that one practices every science until it becomes like his profession and then it will be called $\sin ^{a} a{ }^{c}{ }^{58}$

\section{Fann and șināa in other dictionaries}

Other types of Arabic dictionaries, such as works devoted to furūq (synonyms) ${ }^{59}$ and isțilāhăt (technical terms), do not provide much help in the case of fann. ${ }^{60}$ With respect to the root s-n-', in al-Furūq al-lughawiyya
(The Linguistic Synonyms), prepared by al-'Askari (d. after 1010), șun' is compared to 'amal (work) and distinctions are made between șun', 'amal, and fi'l (action); ${ }^{61}$ here sun' is associated with knowledge and is defined as the most specific word of the three: skillfulness (expertise) is associated only with this word. Al-'Askari also gives the Persian equivalents of these words: kār for fi'l, kirdār for 'amal, and kīsh for șun'.

With respect to the iștilāhät dictionaries, in the Kashshäf iștilāhāt al-funūn (The Discoverer of Scientific Terminology) ${ }^{62}$ by al-Tahanawi (d. after 1745), an Indo-Muslim Hanafi scholar who wrote in India, the $s$ - $n$ - 'entry contains special references to work and profession (for instance, al-Bustani's statement that "one practices every science until it becomes like his profession" is already here). Al-Tahanawi also gives the scientific meanings of $\sin ^{-} a$, singling out the five $\sin ^{-} \bar{a} t$ of the logicians: burhān (demonstration), jadal (argument), khițāba (rhetoric), shi' $r$ (poetry), and mughālața (sophism). ${ }^{63}$ Although there is no special entry for fann, as will be seen below, it is clear from his introduction that al-Tahanawi understood the word funūn, as used in the title, to mean "sciences." 64

\section{NON-LEXICOGRAPHICAL USAGES}

To recapitulate, a comparison of the basic Arabic lexicographical meanings of fann and șinā'a shows that until the end of the nineteenth century fann was associated with the meaning of "kinds, variations, and branches" and had a strong connection to language and rhetoric, while $\sin ^{-} a$ was associated with the idea of work, the making of something artificial, and the concept of profession, craft, occupation. ${ }^{65}$

From this comparison one cannot conclude much, because the most ancient Arabic works of lexicography are better characterized as "word lists." 66 These were "thesaurus" lexicons rather than dictionaries, since there was an overwhelming need to understand rare or strange words and derivatives in ancient poetry, the Koran, and the hadith. ${ }^{67}$ Thus, one cannot map the actual semantic fields of these words based on these dictionaries.

Interestingly, in the 1870 dictionary of al-Bustani both fann and $\sin ^{-} \bar{a}^{\prime} a$ are associated with 'ilm, i.e., knowl- 
edge, science, or scholarship. To detect if there was such a link outside the lexicographical tradition before the nineteenth century, one should consult the entire intellectual corpus of Arabic medieval literature-an impossible task. Here, my aim can only be to highlight some possible points of departure.

Furthermore, it must be kept in mind that Ottoman Turkish, Persian, and Arabic were three languages that stood in mutual interplay, at least concerning technical or specialized vocabularies. The terms fann, $\sin ^{-} a$, and 'ilm, along with their derivatives, continue to be used in Persian and (modern) Turkish today. Because of my limitations, I cannot deal in great depth with all of these languages, although in what follows I will cite some examples I hope will be helpful.

\section{Ș-n-` as craft/knowledge/art}

Although it may be widely known, we should comment on $\sin _{\bar{a}}{ }^{\prime} a$ as the translation of the Greek technē and on the later usage of șan'a (șan'at) in Ottoman Turkish. The translation of Greek scientific texts involved the invention of new words/forms and new meanings. In the case of techne, however, there was no need for an invention, since sinna $a$ perfectly matched its meaning. Translating Nicomachus of Gerasa's Introduction to Arithmetic, Thabit ibn Qurra (d. 901) renders technē as $\sin \bar{a} a$ in the meaning of "craft/profession" when explaining the word "philosopher": "they [the ancient Greeks] called in general with this name everyone who was a skilful and practiced expert in one of the crafts [șinā'a min al-șanā' ${ }^{\prime}$ ] or professions until Pythagoras restricted the meaning of this word." 68 When explaining the different kinds of sciences and their applications, Nicomachus cites Androcydes, according to whom the (craft/science of) painting (zögraphia ${ }^{69}$-rendered into Arabic as șinā'at al-tașawwur-is a knowledge that can be used in many different professions (works). ${ }^{70}$ It might be that Thabit ibn Qurra canonized certain translations such as $\sin _{\bar{a}}{ }^{\prime} a$ for techne, since his good knowledge of Greek granted him a certain authority on the matter-although his mother tongue was Syriac. ${ }^{71}$

In the early Arab classifications of the sciences, it is not easy to decide the exact modern English translation of șināa $\bar{a}^{-}$. For instance, Qusta ibn Luqa (d. ca. 913) dis- tinguishes between four types of șinā' $\bar{a} t$ (translated by Elaheh Kheirandish as "craft/science"): "linguistic" (kalämiyya), practiced by means of the language, as in poetry; "productive" (filiyya), practiced through instruments and actions, as with carpentry; "operative" ('amaliyya), practiced by means of the hands or the body, as in dance or the crafts of war; and "collective" $\left(j a \overline{m i} i^{\prime}\right)$, those that have a share in all of the aforementioned types, such as medicine. ${ }^{72}$ In this case, we might perhaps consider for $\sin _{\bar{a}} a$ the translation "human activity/occupation."

Another example is the translation of and commentaries on the Aristotelian Poetics published by alBadawi. ${ }^{73}$ There remains some controversy around the translation of Abu Bishr Matta b. Yunus (d. 940), but he translated the Greek poietikēs (perhaps via Syriac) as the "science/craft of the poets" (șinā'at al-shu'arä). ${ }^{74}$ Al-Farabi (d. around 950) uses the same phrase in his commentary; Ibn Sina (d. 1037) famously defined poetry as kalām mukhayyil mu'allaf (imaginative and composed speech), but in the conclusion he uses instead of șinā'a the phrase 'ilm al-shi' $r$ (science of poetry). ${ }^{75} \mathrm{In}$ his Shifä', Ibn Sina uses the title Fann al-shi'r, though clearly not in the modern sense of "art," but simply meaning a branch of logic based on the Neo-Platonic Greek prototype. ${ }^{76}$ If I may use a metaphor, for Ibn Sina knowledge is a tree and poetry is one of its branches.

Ibn Rushd (d. 1198) returns to $\sin _{\bar{a}} a$ a (also applying it to madī [panegyric], etc.). ${ }^{77}$ His is a very exact translation of what was connoted by the Greek poietikēs, i.e., a techne that was not an art but a kind of knowledge and "human activity in general."78 To translate this Greek meaning to Arabic, it was enough to refer to the already existing Arabic vocabulary. ${ }^{79}$ Outside of philosophical circles, perhaps even before Aristotle was translated into Arabic, $\sin ^{-} a$ can be found used as a synonym for poetry in the writings of the poet Abu 'l-'Atahiyya (d. ca. 826). ${ }^{80}$

Sinā' $a$ and 'ilm were used in opposition to one another in the famous debate about whether medicine was an "art/craft" (technē, șinā'a) or a "science" (epistēmē, 'ilm). Gerhard Endress has suggested that this dispute concerns the philosophical or non-philosophical nature of medicine, that is, who may teach medicineand here $\sin ^{-} a$ would correspond to philosophical understanding. ${ }^{81}$ 
Naturally, the words $\sin ^{\prime} a$ and șan'a continued to be used in Arabic texts throughout the Middle Ages outside the realms of philosophy and poetics, in the sense of skill, craft, and workmanship. In intellectual circles, different kinds of discourses were dedicated to the senses and creative imagination, as in the essays of the mysterious group of authors known as the Ikhwān $a l-s q a f \vec{a}^{\prime}$ (Brothers of Purity), as well as of al-Ghazali (d. ca. 1111) ${ }^{82}$ With respect to these essays, today some assume that there was no connection between those who created the beautiful objects and those who were thinking about the creative faculties in Arabic, until the fifteenth century. ${ }^{83}$ This assumption, however, cannot be verified in the case of Arabic poetry-we have numerous testimonies from poets on their conceptions of poetry (on which see below). ${ }^{84}$

\section{Șan'at in Persian and Ottoman Turkish}

The words themselves were appropriated by Ottoman Turkish and Persian writers (e.g., Ottoman Turkish șan'at, in the sense of "craftsmanship"; Persian șan'atgarī, "skill, craft, art"). Comparative studies of texts on calligraphy, architecture, music, images, poems, and ornament are required to map the exact process through which the Arabic root $s-n$-' gradually developed a new (?) meaning in these languages.

Based on recent studies, it is justifiable to say that in Ottoman and Safavid territories, beginning in the late fifteenth century, some of the crafts, especially writing/ calligraphy, arts of the book (e.g., illustrated books), ${ }^{85}$ and architecture started to be seen as independent and even metaphysical (and sometimes mystical) forms of creative expressions. The birth of Arabic calligraphy ${ }^{86}$ in the tenth century in a way foreshadowed these later developments. As David J. Roxburgh showed in his analysis of the prefaces of sixteenth-century Persian albums, an art/craft historical consciousness is detectable concerning the pictorial arts as expressed in the Persian language. In these texts, hunar (skill) and șan'at are used to denote "craft/art," although fann is also present, and one might wonder if the phrase fann-i hunarvari ("the art of skill") had anything to do with the later Arabic usage of the word. ${ }^{87}$ Writing, or the art of writing, is rarely called a fann in the Arabic texts to which I had access; instead, it is usually referred to as sinā at al-kitāba or al-khatt (calligraphy). ${ }^{88}$ As seen earlier, this is because of the basic meaning of $\sin ^{-} a$, namely, "the process by which something is made by hand."

The extant Ottoman texts on architecture from the sixteenth and seventeenth centuries point to the fact that at the very least Ottoman architecture and the architectural genius were indeed regarded as an independent creative category, ${ }^{89}$ and that the word șan $a(t)$ was beginning to be used in Ottoman Turkish exactly as ars was in Latin. In their translations of sixteenthcentury Ottoman Turkish sources on the life of the great architect Sinan, ${ }^{90}$ Howard Crane and Esra Akın used "art" for șan'at. ${ }^{91}$ In a poem, fann (fenn, fen) is rendered as "science" (hüner qısmın tamām itdi bu fennde "his abilities in this science he did perfect"). ${ }^{92}$ Both translations mirror the current usage of these words in Turkish. The English version of șan'at is significant here, since "art" can be understood as "craft." In this text, fenn is clearly used as an "area of expertise," standing alone as a synonym of "ilm (for example, fennümde haylì ustādum ["in my science I am very much a master"]). ${ }^{93}$ By the sixteenth century, architecture had surely come to be regarded as a science ( $\left.{ }^{\prime} \mathrm{lm}\right),{ }^{94}$ for which fenn is here a synonym. This is also an early example of how the Arabic fann (branch), after a metonymical transfiguration, became the Ottoman Turkish fenn (science).

Crane and Akın translate the Ottoman Turkish

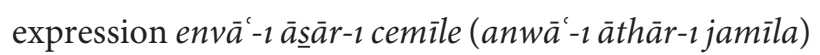
as "beautiful works of art." As will be seen below, this expression would remain current in Ottoman Turkish until the twentieth century. ${ }^{95}$ It must be noted that in this text the phrase is used in reference to a "courtyard fountain," as well as to "spouts," "doorways," and "balconies," all of which serve to demonstrate the skill and mastery of the architect and the decorators. ${ }^{96}$

In the biographies of Sinan, the word șan'at signifies a creative craftsmanship that is transcended by two powerful metaphors: a metaphysical relation to God's creative work (here: șanāyic $\left.\left[s \underline{s a n} \bar{a}^{\prime} i^{\prime}\right]\right)^{97}$ and the mythical skill of the Persian Ferhad, ${ }^{98}$ who cut a road through the Bisutun Mountain for the love of Shirin. The following lines are from a poem (as translated by Crane and Akın) about Sultan Selim's mosque in Edirne: 
nezaket-i diqqat ü hem-resm-i hey'et

muhașṣal hatm olupdur anda șan'at

subtle in refinement and of the same manner in form:

In sum, art attains in it complete realization. ${ }^{99}$

Thus, as Necipoğlu underlines, creative, artistic power (here art is șan'at) was seen as a "pouvoir spécifique conféré par Dieu à l'artiste."100

Sixteenth-century Persian album-makers also compared their productions to the creative work of God, or metaphysical locations (the albums mirrored heavens, and thus were named "celestial albums"). ${ }^{101}$ Roxburgh convincingly argues-based on the conscious usage of biographies of calligraphers and painters in the Persian album prefaces-that the "arts of depiction" enjoyed a high status in late Timurid and early Safavid courts; there might thus be striking similarities with the medieval European patron-artist relationship. ${ }^{102}$ In Ottoman Turkish texts of the same epoch (which were known in the Arab lands as well), ${ }^{103}$ architecture was regarded as a creative, distinguished-even divine craft, i.e., șan'at, which definitely refers to more than technical skill. For Sinan, a building was "a material trace of its makers' mental powers of invention."104

Written in the early seventeenth century, the Risāle-i Mi'māriyye (Treatise on Architecture) by Cafer Efendi (fl. early seventeenth century) provides an example of a Persian-Ottoman Turkish-Arabic interplay of architectural technical expressions: "Amal and șan'a are Arabic. In Persian they say kār and pisha. In Turkish they say iş and peşe. Șinā $a$ and hirfa are also Arabic. In Persian they say pisha, in Turkish șan'at." ${ }^{105}$ Here, "craft" and "work" are the meanings of șan'at.

The author also explains: "[Ș]inā' $a$ is Arabic. In Persian they say pisha. In Turkish, the common people corrupt it and say peşe." Cafer Efendi goes further with hirfa, which in Persian is pisha and in Turkish pişse and $s_{c}{ }^{\prime}$ ' $a$. In contrast, the Arabic șan' $a(t)$ is rendered in Persian as dastkāri $\bar{i}$, while in Turkish he simply uses the Arabic word. ${ }^{106}$ For all these words, the English translator, Howard Cane, gave the meanings "craft, art." This is justifiable because in the early seventeenth century the craft of architecture could easily have been rendered in English as the "art" (that is, the science, or craft) of architecture. However, for hirfa perhaps "profession" would be a better fit (this is the way Crane translated the Persian pisha). Yet Cafer Efendi in these cases did not use the word fann.

The texts of Sinan compellingly point to the appropriation of șan'a(t) in Ottoman Turkish (and later sanat in modern Turkish) with a connotation of creative, divine work; this meaning would be responsible for the use of this word to translate the nineteenth-century European word "art,"107 since san' $a(t)$ already carried the meaning of an independent sphere of human activity, based on its close association with architecture, book illustrations, and all kinds of creative and beautiful crafts, as well as the creative genius behind them. Yet it is even more curious why in Arabic this word was not chosen to translate "art."

\section{Funūn and fann: Metonymical experiments}

As fann in the early Arabic lexicographical tradition was often associated with language and speaking, it might prove fruitful to examine how the term was employed vis-à-vis poetry $\left(s h i^{\prime} r\right)$. This might give us clues to the semantic field that was responsible for the final choice of fann instead of $\sin ^{\prime} a$ (or $\operatorname{șn}^{\prime} a$ ) as the way to denote art in nineteenth-century Arabic.

In what follows I will cite examples of fann meaning "genre," "knowledge," and "art," as gleaned from context, given the metonymical potentials of the original meaning of the term, namely, "condition" or "branch." But first it is necessary to examine the medieval understanding of poetry in Arabic and its place among the sciences.

\section{Shi'r as knowledge}

Was medieval Arabic poetry considered a type of knowledge? If so, was it associated with the word fann? Two main points must be touched upon to answer this question-the traditions that place poetry in the hierarchy of sciences and the well-known debate over $m a s ̦ n \bar{u}{ }^{\prime}$ (artificial) as opposed to mațbü (natural) talent.

To start with the latter issue, Albert Arazi notes that the distinction between the "natural" ( $t a b$ ) and "artifical" (san'a) way of composing poems is usually regarded as a distinction between the ancients (pre-Islamic and Bedouin Arabs) and moderns (medieval Arab urban poets). Arazi also argues that $\sin ^{-} a$, that is, the con- 
scious composition of a poem (poetry as professional knowledge), was not regarded by the ancients as less worthy in comparison with the natural way of composing a poem. As was mentioned earlier, by the ninth century, $\sin ^{\prime} a$ was already used as a synonym for poetry, and the word șan'a was also employed in the sense of a creative ability in the writings of the poet al-Jurjani (d. 1078). ${ }^{108}$ While the concept(s) of poetry in Arabic is (are) open to debates that are beyond the scope of this essay, nevertheless, Arazi's claim that $\sin ^{-} a$, the "craft" of poetry, meaning both the composition process and the scholarship of poetry, was not esteemed less than innate talent can be corroborated by two earlier examples.

In one of the first texts of theoretical reflection on poetry, Tabaqāt [fuḥull] al-shu'arä' (The Classes of Poets), Ibn Sallam al-Jumahi (d. 846) asserted that "to poetry belong a professional knowledge $\left(\sin _{\bar{a}} \mathrm{a} a\right)$ and a skill (thaqāfa). The scholars acknowledge these just like all other sorts of disciplines and crafts, "some of which cultivate the eye, others cultivate the ears, others the hands, and again others the tongue" (they thus acquire the expertise with which they are able to make distinctions). ${ }^{109}$ In this early example, one may not detect the idea of poetry as a branch of the sciences found in NeoHellenic traditions, but it already contains the meaning of craft-alluding to the expertise (observation, mu'àyana) by which one is able to make a distinction among poems just as among precious stones, coins, or slave girls, in order to ascertain their real value.

In Kitāb al-Aghānī (The Book of Songs), the admired collection of poems, songs, and poets by al-Isfahani (d. 967), the verb șana' $a$ is very frequently used to mean, simply enough, "to compose poetry." The most telling point at which the noun șan'a must be translated as "skill/art" is when the author talks about those children of the caliphs who composed poetry: "among them the first and most perfect regarding his skill...was Ibrahim b. al-Mahdi" (fa-awwalu-hum wa atqanu-hum șan'atan). ${ }^{110}$

The dichotomy of understanding poetry as an artificial/professional knowledge and a natural talent might be responsible for the difficulty encountered in analyzing the status of poetry among the sciences in the classifications written in Arabic already discussed above.
Furthermore, as Arazi notes, 'ilm al-shi'r referred not only to the educated knowledge of poetry but also to the science of deciding whether a poem was correctly attributed to a poet. Arazi says that due to this "parity" between 'ilm and shi' $r$, from the late eighth century onwards poetry came to be classified along with the religious sciences (Arazi cites Ibn Hazm [d. 1064]). ${ }^{11}$ Others, like Dina Drury, call the bases of this classification the "strategies by which the profession of the 'scholarship in poetry' ('ilm bi 'l-shi'r [!]) was invented."112

Yet there were various kinds of Arabic classifications-inventories of sciences, as Dimitri Gutas calls them ${ }^{113}$-in different eras and divergent views about the hierarchies of knowledge existed even in the same epoch. ${ }^{114}$ Certainly shi' $r$ was regarded as a kind of knowledge-the 'ilm of pre-Islamic times, according to certain traditions attributed to the caliph 'Umar. But in this perspective a system of knowledge cannot yet be detected. As was mentioned earlier, in the ninth century Qusta ibn Luqa classified poetry as a $\sin ^{-} a$ (a human activity) among the kalām $\bar{\imath}$ activities; then, in the late tenth century, Ibn Sina, who was almost contemporary with Ibn Hazm, included poetry among the sciences of logic (see the section above on "Ș-n-' as craft/ knowledge/art").

I would like to stress here the importance of this development. In the second half of the tenth century, different intellectual projects were initiated in order to rethink the system of sciences, or kinds of knowledge, and in general, human activity, in essays written in Arabic, most probably at the instigation of al-Farabi. ${ }^{115}$ At this time, the expression funūn al-ilm was canonized and poetry/the scholarship of poetry was included among the funūn, based on Neo-Platonic examples; however, perhaps this canonization also shows some interplay with the literature on educated and elegant behavior ( $a d a b)$.

The earliest occurrence of the phrase funūn al-ilm is (to the best of my knowledge) by Abu Hayyan al-Tawhidi (d. around 1020), ${ }^{116}$ in his al-Imtā ${ }^{\circ}$ wa 'l-mu'ānasa (The Delight and Friendly Entertainment). Quoting Malik b. 'Umara al-Lakhmi, he mentions that the 'Umayyad caliph 'Abd al-Malik b. Marwan was a master of al-ma' rifa wa 'l-tașarruffī funūn al-'ilm wa 'l-fașāha wa 'l-balāgha ("knowledge and great capac- 
ity in all branches of knowledge and eloquence and rhetoric"). Here 'ilm indicates all kinds of knowledge (religious or theological), since al-Tawhidi previously mentioned that fiqh, hadith, and even poetry were included under that rubric. ${ }^{117}$

Al-Tawhidi participated in the philosophical circles of his time and one might suspect some sort of interplay between his usage of the phrase funūn al-ilm and Ibn Sina's classification of the sciences into funūn at almost the same time, in the late tenth century. ${ }^{118}$ That poetry is included in both funūn al-'ilm classifications (with significant differences, of course) could follow equally from Neo-Hellenic traditions and ancient Arabic traditions of poetry, since both regard it as a type of 'ilm. Thus poetry became a fann because it was 'ilm.

From the tenth century onwards, the designation funūn al-ilm appeared in different kinds of Arabic and, later, Persian and Ottoman Turkish writings. The rethinking of the sciences, knowledge, and human activity in general also continued and new types of classifications were born, the most important being that of al-Ghazali in the late eleventh century. ${ }^{119}$

Later, some scholars, such as Ibn Khaldun (d. 1406), recognized poetry as a very special type of knowledge. He talks about $a d a b$ as a science "that has no object" ( hādhā 'ilm lā mawdī' la-hā). Its two "fruits"-poetics and rhetoric-are denoted in the dual of fann (fannān). ${ }^{120}$ What is the exact meaning of fann here"requirement of elegant behavior," perhaps? ${ }^{121}$

\section{Funūn as genres/themes}

In its association with poetry (fann al-shi ${ }^{i}$ ), fann was not limited to the meaning "branch of knowledge." The expression funūn al-shi' $r$ is perhaps older than funūn al-ilm. Already in the ninth century, al-Jumahi, again in Tabaqāt [fuhūul] al-shu'arä', employs it to mean "genres/themes": for instance, the companions of al-A'sha said that this poet surpassed them all in funūn al-shi ${ }^{i}{ }^{122}$ In this translation, one sees a transfer of meaning from "branches" to "genres."

In al-Isfahani's Kitāb al-Aghānī as well, the term occurs three times. In one instance, the seventh-century poet al-Hutay'a (a Muslim convert) is described as "capable of composing in all the genres of poetry" (mutașarrif fī jamī funūn al-shi' $r$ ). These genres, the funūn in this quotation, were madìh (panegyric), hija $\bar{a}^{\prime}$ (insulting poem, satire), fakhr (self-praise), and nasīb (love poem/prelude). ${ }^{123}$ This classification was already invented by al-Jumahi, and in contrast with my use of the term "genres," sometimes these are also labeled in scholarship as "poetic themes." 24 Another occurrence is in a saying about al-A'sha, when it is stated that if someone wants to compete with him, he needs to be well-versed in madi $h$, $h i j \bar{a}^{\prime}$, and "all the genres of poetry" (sä'ir funūn al-shir r). ${ }^{125}$ Fann in the sense of a "poetic genre/theme" also appears in the poetic anthology of al-Tha'alibi (d. 1038) entitled Yatimmat al-dahr (The Epoch's Incomparable). ${ }^{126}$ In the fifteenth century, alIbshihi (d. 1446), in his literary collection al-Mustatraf fì kull fann mustazraf (A Passionate Renewal in All Elegant Arts [of Knowledge]), at one point clearly employs funū $n$ in the sense of "genres." ${ }^{27}$ He divides poetry into eighteen types of fann (funün al-shi'r), namely, the different genres such as the ghazal, the wasf, and so forth. ${ }^{128}$ Later, in the seventeenth century, the Ottoman Turkish scholar Katib Çelebi (d. 1657) also uses the term in this sense in his great bibliographical dictionary, written in Arabic, Kashfal-zunūn (Unveiling of the Doubts), when discussing Abu 'l-'Abbas Ahmad b. 'Abd al-Salam al-Kuwari's collection of poems. ${ }^{129}$

The phrase funūn al-shi'r thus indicates that poetry has various branches (genres). It might have been employed even earlier than the phrase fann al-shi' $r$, which, from the late tenth century onwards, denoted poetry as one branch of the system of sciences, more or less synonymous with șinā' $a$ and 'ilm. To sum up, funūn al-shi ${ }^{i} r$ means that poetry is a category with sub-categories (its genres/themes), while fann al-shi'r means that poetry is a subcategory of a larger system (the hierarchy of sciences).

\section{Fann as sophisticated knowledge}

From the tenth century onwards, the word fann, together with its plural, funūn, was increasingly used in connection with various scientific activities and thereby acquired a very wide semantic potential. It is thus very difficult to provide exact translations of its non-lexicographical usages.

Be that as it may, the idea of fann as ars (meaning the branches of $a d a b$, elegant behavior, refined knowledge) or as a craft became firmly canonized in the fourteenth and fifteenth centuries, as is observable in the title of 
the famous encyclopedia of al-Nuwayri (d. 1332), Nihāyat al-arab fì funūn al-adab (The Ultimate Goal [Utmost Desire] in the Branches/Arts of Elegant Behavior). ${ }^{130}$ Mention should also be made once more of alIbshihi's fifteenth-century work al-Mustațraf fì kull fann mustazraf.

Al-Nuwayri uses fann in different senses. The first one, of course, is fann al-adab: the knowledge or art of $a d a b$ itself. This comprises five branches (funūn): astronomy, the aerial phenomena, and geography; the human being and its activities; animals; plants; and, lastly, history. Nevertheless, he also uses fanan/fann metaphorically when he states that "he made the craft of writing his branch [fanan, i.e., his occupation], under whose extended twigs he could find shade." But "[in the shade] he made diverse kinds of what was collected of old and new possessions" (fanna-hu alladhī jumi'a la-hu fi-hi bayna talìdi-hi wa-țarifi-hi); that is, in his book he rearranged what he had studied previously. ${ }^{131}$ Hence, fann here refers to a field or a category of knowledge. ${ }^{132}$ It is for this reason that I am reluctant to translate the word funūn in al-Nuwayri's title as "arts," although it seems to me that al-Nuwayri canonized $a d a b$ as a fann.

It is tempting to translate fann as "art" in the title of al-Ibshihi's fifteenth-century work al-Mustatraf $f \grave{i}$ kull fann mustazraf. It is perhaps the first time in a text (in a title, no less) that fann stands on its own metonymically. Al-Ibshihi's book is a compilation of different literary genres, containing various stories, anecdotes, and poems, as well as citations from the Koran and traditions about the life of the Prophet. He himself says that his aim was to collect all fann zariff, which might be translated as "the elegant/charming/witty arts." 133

The word zarif was often used in the ninth and tenth centuries to refer to elegant/witty/educated knowledge. When applied to a person, the closest translation would be "gentleman." To become a zariff, a status that also had a social and ethical meaning (including friendliness, tolerance, good morals, and so forth), one needed adab, "elegant behavior," which, as Doris BehrensAbouseif has pointed out, even covered personal hygiene, ${ }^{134}$ though its main feature was poetry. Al-Ibshihi's usage clearly indicates that fann had become an independent word meaning "art" in the sense of a knowledge that is needed for acquiring $a d a b$ (ars). It should be noted that in medieval Andalusian Arabic fann and funūn seem also to have meant "field of knowledge" (fourteenth century) and, in some versions (i.e., tefennún, mufénnin), "sophistication." 135 Thus, between the twelfth and fifteenth centuries, the word fann acquired in Arabic, via a synonymic process, the sense of sophisticated, elegant, witty, useful genre(s) of knowledge.

This was, of course, not an exclusive meaning of fann; serious counter-examples can be cited to show that, even if the above hypothesis is true, this meaning had not yet been crystallized or generally canonized in Arabic. For instance, in India, as late as the eighteenth century, al-Tahanawi clearly used funūn in the sense of "science" in his Kashshāf iștilāhāt al-funūn; he included all the "hard" sciences among al-'ulüm al-haqiqqiyya (the essential sciences). For al-Tahanawi, the latter were those sciences that "are the same everywhere regardless of different peoples or religions," such as geometry. ${ }^{136}$ It must be mentioned that fann/fenn was also used to mean "science" in both Ottoman Turkish and Persian. ${ }^{137}$

In Egypt, at roughly the same time in the eighteenth century, al-Zabidi referred to the science of lexicography as al-fann in the introduction to his great dictionary Tāj al-'arūs. ${ }^{138} \mathrm{He}$ also referred to the sharh (commentary) of certain dictionaries as al-fann, ${ }^{139}$ stating that he regarded these commentaries, by metonymy, as "a branch of the sciences." Thus, even in the eighteenth century al-fann was used in Arabic to denote both science and literary, elegant, witty knowledge.

\section{Entertainments and fann}

Apart from poetry, prose, and architecture, certain creative expressions and forms of entertainment are considered part of the "arts" today: image-making/painting and performative arts such as music, dance, and singing, as well as shadow theater, puppet theater, and the art of story telling. None of these was called a fann in the medieval texts to which I had access.

The case of music (mūsìq $\bar{\imath})$ is misleading, since, as Behrens-Abouseif has shown, it was either regarded as a theoretical science ${ }^{140}$ and thus called an 'ilm or a șinā $a$ in Arabic, or distinctions were made between the effects and the craft/art of music. ${ }^{141}$ There are a few cases in which fann al-mūsiqù /mùsìqā is regarded as a branch of 
science. But in these cases, fann simply means that music was one of the funūn al-ilm, such as grammar. Samā', "hearing," is a term used especially for Sufi religious music. Although it was attacked by some theologians as immoral, ${ }^{142}$ it was called an 'ilm in the Futūhàt al-Makkiyya (Meccan Revelations) of Ibn 'Arabi. ${ }^{143}$ Singing (ghina') is a șinā' $a$ and also an 'ilm in the Arabic texts; it is never referred to as a fann. It is sometimes equated with $m \bar{u} s \bar{q} q \bar{i}$ (for instance, in the writings of the Brothers of Purity). ${ }^{144}$ I did not find any case in which dance (raqs) was referred to as a fann, and there are only two instances in which it was called $\sin ^{-} a$, both from philosophers' texts, al-Farabi's Ārā' ahl al-madīna al-fädila wa-mudāddātu-hā (The Opinions of the Citizens of the Perfect City) ${ }^{145}$ and Ibn Sina's al-Shif $\vec{a}$ (The Cure). ${ }^{146}$ Raqs is included in the science of music and called an 'ilm in Katib Çelebi's encyclopedia, Kashf al-zunūn. ${ }^{147}$

\section{A tentative summary}

I would like to propose a tentative hypothesis based on the above data concerning the evolution of the meaning of fann via different metonymical processes in Arabic texts. It seems to me that the earliest usage of fann as "branch" outside of the lexicographical tradition was perhaps in the expression funūn al-shi'r, referring to the genres/themes of poetry. In the tenth century, the phrase funūn al-'ilm was canonized in the meaning of "branches of knowledge," i.e., the sciences, both in literary and philosophical texts. It is possible that this expression was used earlier, but it certainly gained a general favor around this time.

Funūn al-'ilm was canonized because it denoted a system of human knowledge/activity based on the NeoPlatonic arrangement of sciences and included poetry as well among the logical sciences fully outlined by Ibn Sina. Poetry was also regarded as a professional knowledge (i.e., the knowledge [șināa $a$ ] of creating different kinds of poetical expressions) at the dawn of Islam. Later, since the scholarship of poetry was already regarded during Abbasid rule as a science in Greek philosophy, its classification among the sciences gained double legitimacy, due to post-Hellenic and early Arab traditions. This is how poetry became a fann in the tenth century and $\sin ^{-} a$ and fann started to be used interchangeably in reference to it.
However, adab, elegant behavior and its arts, comprised not only poetry but nearly all types of literary knowledge. Around the fourteenth and fifteenth centuries, the meaning of fann crystallized in its plural as "arts/sciences" (funūn) via a metonymic process. Adab in the sense of charming, literary knowledge and elegant behavior included all these funūn. The expression fann zarif seems to be crucial for describing the branches of adab (funūn al-adab), and I am tempted to discover already in al-Ibshihi's usage the independent meaning of fann as art.

This convention was not exclusive and a plurality of meanings and context-dependent usages can be found in different types of texts in Arabic, including the wellestablished use of fann in connection with any science. In Ottoman Turkish and Persian, this meaning of fann was inherited. By contrast, in these languages, the words $\sin ^{\prime} a$ and $\sin ^{\prime} a(t)$, as used in reference to a conscious work by an artist (e.g., architects, image-makers, poets, and calligraphers), were filled with a metaphysical sense of creative force.

Hence, due to numerous developments prior to the nineteenth century, fann came to be understood as a knowledge that was required for the fulfillment of a science or as a part of elegant behavior. However, this was not its exclusive meaning. Furthermore, the words $\sin ^{-} a$ and șan'a clearly covered a more specific connotation of creative ability/art/craft in Ottoman Turkish and Arabic. Yet there are examples in Arabic texts in which fann was used as a synonym of șinā'a in the case of poetry. To repeat, fann became primarily associated with literary, educated, elegant knowledge.

\section{FANN IN THE NINETEENTH CENTURY}

The Western European concept(s) of art, or "fine arts" developed since the Renaissance, and was (were) reformulated during the Enlightenment period. Vasari in the sixteenth century was the first to codify the fine arts (painting, architecture, sculpture), although earlier conceptualizations of the fine arts were suggested by Alberti. During this time, the Ottoman Empire ruled most of the Arabic-speaking territories. Although there are already in the eighteenth century many descriptions in Ottoman Turkish of different institutions of Euro- 
pean art, in Arabic these occur only in the nineteenth century. There are two main reasons why Arabic was exposed relatively late to the challenge of the translation of new concepts and phenomena.

First, foreign expressions were translated into Ottoman Turkish as the language of administration. Second, the Arabic territories did not have official representatives in Europe, since, with the exception of Morocco, they were still part of the Ottoman Empire in the seventeenth and eighteenth centuries. It was thus in Ottoman Turkish that ambassadors and diplomats of the empire recorded their European experiences in this period. Although European merchants and consuls dwelled in various Arab cities (especially port cities), these did not have much influence on intellectual life before the nineteenth century.

Ottoman Turkish ambassadorial reports (sing. sefäretnāme) are a crucial source for the history of ideas. Twenty-three such documents from the eighteenth century focus on various European capitals and contain detailed descriptions of cultural activities such as opera and theater. ${ }^{148}$ Researchers have only recently begun to study these documents, ${ }^{149}$ and to my knowledge the texts have not yet undergone proper linguistic analyses.

Arab travelers also wrote about European entertainments in the eighteenth century. In one such account from 1780, a Moroccan envoy to the Spanish court, Muhammad b. 'Uthman al-Miknasi ("from Meknès") described a Spanish theater. However, he used neither sinā'a nor fann to describe the phenomenon. ${ }^{150}$

The Ottoman court became well-versed in the European arts during the so-called Tulip Period in the early 1700s; later in the century, opera troupes began visiting the palace. ${ }^{151}$ Indeed, Italian and French music and theater have a long history in Istanbul, dating back to the fifteenth century. ${ }^{152}$ However, there is not yet much data concerning the words used for these entertainments in Ottoman Turkish, though surely the term șan'at remained current. The "Western modality of art," as Wendy Shaw calls European painting and its traditions, was theorized publicly in Ottoman Turkish only in the late nineteenth century, first in $1889 .{ }^{153}$

As for Arabic, the period when fann became synonymous with $\sin ^{c} a$ is hard to detect precisely in medieval and early modern Arabic lexicographical works.
Even in al-Bustani's nineteenth-century Muhìt, poetry is still defined as a type of 'ilm and kaläm, rather than as a fann. ${ }^{154}$ In this section I will first focus on nineteenth-century Arabic dictionaries, since these are also crucial for nineteenth-century translations, with an outlook to late Ottoman Turkish dictionaries. Second, I will highlight some aspects of the reform of education and the work of the imperial administration. Third, two important early nineteenth-century Arabic texts will be mentioned, Rifa'a Rafi al-Tahtawi’s description of Paris from 1830-31 and Ahmad Faris al-Shidyaq's description of Malta and Europe in 1836. Fourth, I will suggest further considerations about the role of the early Arabic press in the dissemination of the term fann.

\section{Fann and art in nineteenth-century lexicography}

The most important Arabic-Latin dictionary was the Lexicon Arabico-Latinum of Jacob Golius (d. 1667), ${ }^{155}$ which, published in 1653, remained a fundamental work in Orientalist scholarship until the nineteenth century (for a comparative chart of the listed entries in this section, see table 2). Golius based his lexicon on the Sih the Mujmal of Ibn Faris and various Arabic-Ottoman and Arabic-Persian dictionaries. ${ }^{156}$ Here, fann is translated as species rei, modus, ratio, pars artis (part of the crafts), doctrinae, defraudatio (being cheated), and finally, ornatus, based largely on the Sihāh. ${ }^{157}$ This is a more or less faithful rendering of the Arabic lexicographical tradition, which also shows some understanding of non-lexicographic Arabic usages.

Yet it is worth noting that Golius translated jarîf, ${ }^{158}$ hirfa,${ }^{159}$ and $\sin \bar{a}^{-} a$ into Latin as ars. ${ }^{160}$ Earlier, we examined the terms hirfa and șinā'a in the meanings of "profession" and "craft/knowledge." In the translation of the entry on jariff, Golius also cited the Persian word pishe, which, as we have seen, in the seventeenth century was the equivalent of Ottoman Turkish șan'at, and thus meant "craft/art." Yet this pattern, $f a$ ' $i l$ for the root $j-r-f$ is only found in the meaning of a "dried" ( $y \bar{a} b i s)$ plant. Following the proper usage of ars in medieval Latin in the sense of "craft," Golius also employed that term in his translation of subjects such as cooking ( $t i b \bar{a} k h a)$ and medicine (tibāba)-ars coquinaria (culinary art) ${ }^{161}$ and ars medica (medical art), respectively. ${ }^{162}$ 
Table 2. Entries on art, fann, and șināa $a$ in nineteenth-century dictionaries. Nouns and verbs are classified together and only selected meanings are given.

\begin{tabular}{|c|c|c|c|c|}
\hline Author & Year published & Word & Plurals & Translation \\
\hline Ruphy & 1802 & art & & $\sin \bar{a}^{\prime} a$ \\
\hline $\begin{array}{l}\text { Raphaël de } \\
\text { Monachis }\end{array}$ & 1822 & arte & & $\sin ^{-} a, \operatorname{san}^{\prime} a$ \\
\hline $\begin{array}{l}\text { Raphaël de } \\
\text { Monachis }\end{array}$ & 1822 & artifizio & & fann, $\sin ^{\prime} a$ \\
\hline Bochtor & 1828 & art (as method/craft) & & fann (funūn, afānīn), șinā'a \\
\hline Bochtor & 1828 & art (as skill) & & $\sin ^{\prime} a-\operatorname{san} a-h u s n$ ma'rifa \\
\hline Freitag & $1830-37$ & fann $(a)$ & funūn, afnān & $\begin{array}{l}\text { to drive away a camel, kind, } \\
\text { sort, etc. }\end{array}$ \\
\hline Handjéri & 1840 & art (as method/craft) & & $\operatorname{șan}^{\prime} a$, fann \\
\hline Handjéri & 1840 & les beaux arts & & funūn sharīfa \\
\hline Anonymous, Beirut & 1857 & art & & fann, $\sin ^{\prime} a$ \\
\hline $\begin{array}{l}\text { Biberstein- } \\
\text { Kazimirski }\end{array}$ & 1860 & $\operatorname{ssan}^{\prime} a / \sin ^{\prime} a$ & & art, craft, industry \\
\hline $\begin{array}{l}\text { Biberstein- } \\
\text { Kazimirski }\end{array}$ & 1860 & fann & funūn, afnān & class, science, ornament, art \\
\hline Lane & 1863 & $\begin{array}{l}\operatorname{fann}(a) \text { (all medieval } \\
\text { forms) }\end{array}$ & $\begin{array}{l}\text { funūn, afnān, } \\
\text { afānīn, etc }\end{array}$ & $\begin{array}{l}\text { drove away, delayed, deferred, } \\
\text { sort, species, mode, manner } \\
\text { etc }\end{array}$ \\
\hline Butrus al-Bustani & 1870 & fann & $\begin{array}{l}\text { funūn, afnān, } \\
\text { afānīn }\end{array}$ & $\begin{array}{l}\text { to drive away a camel, etc. } \\
\text { kind, sort, craft, science, } \\
\text { written essays }\end{array}$ \\
\hline Salmoné & 1889 & fann $(a)$ & & $\begin{array}{l}\text { varied, diversified, adorned, } \\
\text { decorated, kind, art, branch }\end{array}$ \\
\hline Belot & 1890 & art (as method/craft) & & $\sin \bar{a}^{c} a$ \\
\hline Belot & 1890 & les arts libéraux & & fann / funūn \\
\hline Belot & 1890 & les beaux arts & & nawādir al-funūn \\
\hline
\end{tabular}

Many dictionaries of European Orientalist scholarship have not yet been studied comparatively, though this might be crucial for determining the European or Latin understandings of Arabic concepts. For Latin, Georg Freytag's Lexicon Arabico-Latinum (published 1830-37), which was based on the Qāmūs, repeats that of Golius: Freytag defines fann, as species, classis rei, modus, and ratio. ${ }^{163}$

Before the nineteenth century, bilingual dictionaries of a particular national language and Arabic existed but were rare. The first nineteenth-century French-Arabic dictionary was J. F. Ruphy's abridged 1802 work, which was intended for commercial purposes: its entry for "art" contains only the term șināa $a .{ }^{164}$ The first printed book from the famous Bulaq Press in Egypt, an ItalianArabic dictionary by Raphaël de Monachis published in 1822, offers $\sin ^{-} a$, șan' $a$, hirfa, and mihna in the entry on "arte." For "artifiziale," it gives mașna" and 'amalì, but "artifizio" is fann, șinā'a, and hirfa (!). Interestingly, "artista" is still șinā'iti or șāni ${ }^{\prime}{ }^{165}$ In the the- 
matic section, "un Musico" is defined as min ahl al-malāib wa 'l-manāzir ("a person of the playhouseand spectacle-folk"). ${ }^{166}$

Perhaps the most important French-Arabic dictionary in the early nineteenth century was Ellious Bochtor's Dictionnaire français-arabe, which first appeared in 1828. Here the word "art" is understood to be a "méthode pour faire un ouvrage selon certain règles, fann; pl. funūn, afānīn; șināa a, pl. șanāyi '. Fann has an autonomous meaning and is synonymous with $\sin ^{-} a$ in this dictionary; this is most likely based on the nonlexicographical usage and the interplay (analyzed above) between sinā'a, 'ilm, and fann. Art in the sense of "skill"-French "adresse"-is șināa-șan'a-husn ma'rifa, and an "ouvrage de l'art, opposé à ouvrage de la nature" is translated as șan'a didd khilqa. The word "artifice," in the meaning of "finesse, manière adroite de faire," is rendered as fann or $\sin ^{-} a(!) .{ }^{167}$ In the 1869 edition, "artiste," that is, one "qui travaille dans un art où le genie et la main devoint concourir" is mu'allim-ustādh-ahl șinā'a yalzam fì-hà 'amal al-'aql wa 'l-yad, a word-for-word translation of the French. "Artistement," meaning "avec art," is bi-șan'abi-sināaca. ${ }^{168}$

As it is germane to our discussion, it is worthwhile to explain how this dictionary came into being. The author, Ellious Bochtor (d. 1821), was a Copt from Egypt, one of those, "who in the wake of the French occupation came to play a not insignificant part as cultural intermediaries between their homeland and their country of adoption." 169 After serving as a translator for the French army in Egypt, beginning in 1812 Bochtor performed the same duties in Paris for the Dépôt général de la guerre. In January 1821, he was appointed to the post of Arabic teacher (professeur d'Arabe vulgaire) at the École des Langues orientales in Paris but died in September later that year. ${ }^{170}$

His dictionary was most probably an initiative of the French state, perhaps the Ministry of War, since already in 1806 the Institut de l'Egypte had addressed Napoleon about the importance of such a project. Bochtor worked on it continuously from 1812 until his death, although practically every year he was fired and then hired again. ${ }^{171}$ When he died, this dictionary remained unfinished.
The Orientalist Arman Caussin de Perceval (d. 1871), who succeeded him in his post at the École, was asked by Marquis Amédée de Clermont-Tonnerre (d. 1859), an ardent French patriot who had acquired Bochtor's manuscript, to finish and edit the dictionary. Caussin de Perceval recounts how he enriched ("quelques augmentations") Bochtor's manuscript-which concentrated mainly on current usages-with the following: material from his own collection from Syria; material he judged useful from a Spanish-Arabic and an ItalianArabic dictionary; and, he also admits, the work of Golius. It is no wonder that in the end Caussin de Perceval remarks that his additions comprise approximately half of the final edition. ${ }^{172}$

$\mathrm{He}$ also explains that when there was no equivalent for a French expression both he and Bochtor used paraphrases in order to help those Arab students who wanted to study French. Thus it is impossible to determine which entries are the work of Bochtor as opposed to de Perceval. As could have been foreseen, the terms șan $a$ or $\sin ^{\prime} a$ appear in almost all the entries on "art." Fann is found in two entries: one on "art," in the sense of the method of creating something (perhaps a craft?), and another in the sense of "finesse," meaning knowledge or know-how. Based on the lexicographical and non-lexicographical Arabic meanings of fann, this choice can be justified considering the eighteenth-century usage of the word (e.g., al-Tahanawi and al-Zabidi in their introductions). It is, however, striking that for the new "artistic" sense of art, the author offers either sinā' $a$ or șan' $a$, in accordance with the Ottoman Turkish and Persian usages. Fann is not associated with "artist," or with "artistic" meanings, although it still occupies an equal place with $\sin ^{-} a$ in the translation of the French "l'art" as a method. Raphaël de Monachiswho actually preceded Bochtor in the Chair of Arabic at the École-had already used fann and $\sin ^{-} a$ in his Italian dictionary.

In the Dictionnaire français-arabe-persan et turc of Alexandre Handjéri (published in 1840), "art" as a method/craft is translated as in Bochtor (Arabic șan'a, fann, with the addition of Persian pishe and Turkish sinā'at), but with a very rich (Ottoman Turkish) exemplar: "les termes de l'art: iștilāh-i șan'at, règles de l'art: qawāid-i șan'at - qawā'id-i fann, le sublime de l'art: 
'aluww-i qadr-i fann, l'art de la Poésie: fann-i shi'r.' Prince Handjéri also provides an interesting remark: "On appelle Beaux-Arts, la Peinture, la Sculpture, l'Architecture, la Musique, la Poésie, l'Éloquance funūn sharīfa-șanāyi sharīfa" (noble arts, noble crafts). ${ }^{173}$ For "artiste," he gives Arabic ahl al-fann (pl. arbāb alfann [!]), Persian fann-i āshnā, and Turkish ustād. ${ }^{174}$ This is a very remarkable entry since the word "artist" would never again appear in a dictionary in connection with fann prior to the twentieth century.

A little later, in a French-Arabic dictionary published in 1857 in Beirut, "art" as a method was rendered as fann and $\sin ^{-} \bar{a} a$, but "artist" remained mu'allim, ustādh. ${ }^{175}$ At roughly the same time, the Arabic-French dictionary of Albert de Biberstein-Kazimirski (d. 1887) (published in 1860) gave a lengthy description for $s-n^{-}$, with all its derivatives. Here șan 'a is "art," just like $\sin ^{\prime} \bar{a}^{\prime} a$ (pl. șanāyi'), meaning "art, métier, industrie."176 In the same work, fann has nine meanings, ranging from "classe" through "chapitare" and "ornament" to "art" or "science" (the last meaning). ${ }^{177}$

In his great supplement to Arabic dictionaries (published 1877-83), Reinhart Dozy mentions how fann is used in the The Thousand and One Nights: "parlant d'une jeune fille, kāmilat al-funūn [means] 'possédant toutes sortes de beautés. " 178 Out of the numerous later dictionaries, P. J-B. Belot's French-Arabic dictionary (compiled in the 1880s and published in 1890) gained general favor. Its entry on "art" distinguishes among the different meanings of the term. As a method/craft, it is $\sin \bar{a} ' a$, but in the sense of "les arts libéraux" it is fannfunūn, "les beaux arts" is nawädir al-funūn, and "les arts mechanique" funūn al-hiyal. ${ }^{179}$ Yet, the "artist" is māhir $f_{i} \sin ^{-} \bar{a}^{\prime} a$ (expert in a craft) and "artistement" is rendered as bi-taqāna (with perfection), bi-șināa $a$. It seems that the meaning of art procured the most detailed attention in Belot's dictionary, though the current term for "artist," fannān, is not yet present.

Edward Lane's work does not provide any help because his dictionary is based on the medieval Arabic dictionaries, and I have already discussed Butrus alBustani's late nineteenth-century Arabic-Arabic dictionary in the sections entitled "The entries on fann ( $f-n-n$ and variations thereof)" and "The entries on $\sin \bar{a}^{\prime} a$ (s $s$ - ' and variations thereof)." For the verb fanna,
Habib Anthony Salmonés Arabic-English Dictionary (written in the 1880s) gives "varied, diversified, adorned, decorated, delayed, deferred, cheated, drove [camels]; mixed, divided, varied in (speech), well-versed"; for fann, it offers the usual meanings, ranging from "kind" via "art" to "branch." ${ }^{180}$ Edmund Fagnan's Additions aux dictionnaires arabes translates the verb tafannana as "varier le style, l'expression de la pensée," while fann is "métier, profession." 181

I would like to underline that colloquial Arabic, at least Egyptian, should also be considered as an indicator of social change (even more perhaps than dictionaries of written or classical Arabic). The Egyptian colloquial dictionary of Socrates Spiro (written in the 1890s, published in 1895), gives the verbs fannin-iftannin as "to invent, devise," while fann is rendered as "art" and șāhib fann as "artful, skilful."182

Regarding nineteenth-century Ottoman Turkish dictionaries, it is imperative to mention the standard work of J. W. Redhouse (d. 1892), which was written in the 1860s (with an enlarged second edition by Charles Wells published in 1880). For the English word "art," Redhouse provides the following translations: șan 'at, ma'rifet, fenn, and hìle. For "artificial," he gives "șun'ī, mușanna'" while the word "artist" is rendered as ressām. ${ }^{183}$ Redhouse, it is said, based his work largely on the contemporary usage of the words. The presence of șan' $a t$ and its derivatives is natural, based on the previous occurrences of the term, but the appearance of fenn is striking, and my only explanation is that "art" was translated in this way because of the original "craft" meaning of the English word; this is also supported by Redhouse's translation of fenn as "an art" in the phrase hezār-fenn, "a jack-of-all-trades, a person clever at many things." 184 The translation of "artist" as ressām, that is, "draftsman, painter," mirrors the primary usage of "art" in English, where it is mostly applied to the visual arts.

One should not overlook the French-Ottoman Turkish and Ottoman Turkish-French Dictionary (1883) by Sami Bey (d. 1904), where fenn is "espèce," "categorie," "science," "art," and "artifice,"185 while șan'at is "art" and "métier." 186 It would seem that in nineteenth-century European and non-European dictionaries fann became a rival word of șan'a and $\sin ^{-} a$ because of its 
close association with crafts and sciences, just as alBustani had registered it in his dictionary, based on the previous, non-lexicographical usages and perhaps as a reflection of colloquial usage.

\section{Non-lexicographical usages (1820s-60s)}

Dictionaries were only one channel through which foreign concepts were translated into Arabic and Ottoman Turkish. It is also necessary to consider the influence of early nineteenth-century school reforms, as well as the role played by administrative translators, dragomans, travel writers, and the early Arabic and Ottoman Turkish press. Unlike in the eighteenth century, the words used to denote art practices in Europe were increasingly applied to art practices within the geographical area of the Ottoman provinces, e.g., the newly established theaters and the Ottoman/Arab artists trained in the Western modality of pictorial traditions.

Two important Arab territories were Ottoman Syria, where missionary schools were established (primarily by the French, the Americans, and the British), and Ottoman Egypt, where governor Muhammad 'Ali Pasha (d. 1849), an Ottoman officer from Kavala, established new schools. The influence exerted by these educational institutions depended on whether they were primary, secondary, or specialized schools. The Ottoman-Arab elite of these provinces early on acquired French as a second (and in some cases later, almost as a first) language. North African Arab-speaking territories and French port cities (which already had a large Arab population in the nineteenth century) are beyond the scope of this work. Here I provide the example of Egypt, with an outlook to Istanbul.

\section{Schools and Administration}

In Muhammad 'Ali's Egypt, primary school (al-rasmiyya) pupils were also taught in Ottoman Turkish. In the countryside, Arabic was the language of instruction in the kuttäb, traditional schools that taught basic religious learning; the al-Azhar still provided graduate education. In addition to modernizing the army, the Pasha, beginning in the 1810s, established military schools where his Ottoman officers (who were of varying ethnic origins-Turks, Albanians, Kurds, etc.) as well as French,
Italian, and Spanish instructors (mostly ex-soldiers of the Napoleonic era) trained the students/recruits. These were Egyptian Arab peasants who had been conscripted into the army (after the cruel recruitment of Sudanese slaves proved unsuccessful). ${ }^{187}$

The educational system was enriched through the addition of new medical and engineering schools, in which mostly French and Italian professors taught. ${ }^{188}$ These were complemented by schools of military music, in one of which a German professor reportedly trained a band to play European-style music, as well as operas. ${ }^{189}$ There were also confessional schools (Catholic, Coptic, and Jewish) and, in Alexandria, schools for the foreign (Italian and French) communities.

The Egyptian military students were not really exposed to the translation of European arts since their training was rather utilitarian-although the engineers did study drawing. The activity of the music schools was relatively well-documented in the Ottoman Turkish administration of Muhammad 'Ali (Dīwān al-Madāris al-Turkī [Ottoman Turkish Administration of Schools], in the National Archives of Egypt), but I could not find evidence that any examination of "art" was part of the curriculum and, if so, what words were used to describe it. ${ }^{190}$

In addition to schools, civil and governmental societies (and institutions often under missionary influence) were established, such as the Syrian Jam iyya al-Süriyya li 'l-'ulūm wa 'l-funūn (The Syrian Society of Sciences and Arts, 1847), which already made a distinction between science and art in its very name. ${ }^{191}$ The forerunners of universities in Iran and in the Ottoman Empire-the Dār al-Funūn in Teheran (1851) ${ }^{192}$ and the Dār al-Funūn in Istanbul (Dar ül-Fünun, first envisioned in the 1840s, but only opened in 1870)-used fann primarily in the sense of science and branches of knowledge, ${ }^{193}$ based on the well-established traditions of this word in these languages. ${ }^{194}$ Sultan Mahmud II opened many institutions of learning in the 1830s, among them art schools such as the Müzīka-ı Hümāyūn Mektebi (Imperial School of Music) with Guiseppe Donizetti Pasha as director, ${ }^{195}$ and the Mekteb- $i$ Ma'ärif-i Edebiyye (School of Literary Education), where, of course, not only French but also Arabic was taught. ${ }^{196}$ Following earlier experiments, in $1882-83$ an 
Academy of Fine Arts (Sanāyi'-i Nefìse Mektebi) was opened in Istanbul, under the directorship of the famous Osman Hamdi Bey. ${ }^{197}$ This opening signifies the institutionalization of Western European pictorial traditions in the Ottoman capital. ${ }^{198}$

During this time, the Egyptian ruling elite, the governor, and his family spoke Ottoman Turkish. Their translators were usually Armenians or Greeks who knew French and Ottoman Turkish-as well as Italian, since in the first half of the nineteenth-century that language was more commonly used than French for commercial reasons (Italians had been in the Eastern Mediterranean since late Byzantium; there were, moreover, political refugees from Habsburg Italy, who had arrived in the first half of the nineteenth century).

No surprise, then, that the first book to be printed by the Bulaq Press (established in 1822) was the already mentioned Italian-Arabic dictionary of Don Raphaël de Monachis. Although the press was primarily used for military tracts (in Ottoman Turkish) and engineering publications (mostly in Arabic), numerous Ottoman Turkish poetry books were also printed. However, Arabic $a d a b$ works were only produced after the death of Muhammad 'Ali in 1849. Based on the social composition of the elite, there was likely more demand for books of Ottoman poetry than ones in Arabic among the Turco-Egyptian elite; the market for Ottoman Turkish books was much larger than the one for Arabic books (i.e., many books were exported to Izmir or Istanbul). ${ }^{199}$

Yet in the 1830s and 1840s the central administrations increasingly had to deal with "European" artistic issues in Cairo, Alexandria, and Istanbul. There were European music performances and theaters, as well as (Italian) circuses; the state also had to address the concerns of European architects, painters, and decorators, who worked primarily for the rulers' families (in Cairo, for the pasha; in Istanbul, for the sultan and the palace) or were part of private businesses (in the case of theaters). More research needs to be conducted on the activity of early nineteenth-century Ottoman translators in the central and provincial administrations and the semantic solutions they employed in such contexts.

Beginning in the late 1830s, more and more theaters and circuses were established in various locations of
Istanbul, though they were concentrated primarily in Pera/Beyoğlu. If the petitions of those who ran such productions were written in a foreign language (usually French or Italian), they had to be translated into Ottoman Turkish. One example is a letter in French written by a certain Henri Houquet to Reşid Pasha in 1850 in which he requested permission to build a theater in Constantinople-that is, not in Pera/Beyoğlu, where the Naum Theater already existed, but in the Old City. In the first sentence, Houquet praises Reşid Pasha: “c'est Vous qui avait fait fleurir les beaux arts dans la Turquie" (It is you who made the fine arts flourish in Turkey). It seems that in the draft of the translators of the Tercüme Odası (Office of Translation), "les beaux arts" was initially translated as șanayi $i^{\prime}$, this was then crossed out and it was rendered as eşyā- 1 șanā'iyye (artistic things). ${ }^{200}$

With respect to Egypt in the first half of the nineteenth century, I do not yet have any data on the expressions employed for art by the provincial administration, although I suspect that since Ottoman Turkish was the principal language of government, șan'at or one of its derivatives was used. For instance, it would be helpful to know how officials described the Italian theater in Alexandria in the 1830s and the opera performances organized for Muhammad 'Ali in the 1840s. ${ }^{201}$

\section{Travel literature: al-Tahtawi and al-Shidyaq}

Besides the state apparatus, travelers also served as conduits of intercultural exchange. Rifa a Rafi ${ }^{\prime}$ al-Tahtawi (d. 1874), a young sheikh of al-Azhar who later became the grandfather of Egyptian nationalism, wrote a wellknown account of his stay in Paris as an imam of a student group from Egypt. In this work, whose abridged title is Rihla (Travel, written in 1830-31, published in 1834 in Bulaq, and later translated into Ottoman Turkish), al-Tahtawi describes in Arabic contemporary French concepts and practices of law, as well as health policies, religion, and the arts. ${ }^{202}$

Al-Tahtawi had numerous reasons for undertaking this project. First, he may have recognized the utility of writing a report for Muhammad 'Ali Pasha, who had sent this group of students to Paris. Second, his sheikh and main supporter, Hasan al-'Attar, had counselled the young al-Tahtawi to record everything that he learned while abroad. ${ }^{203}$ Third, the French Orientalists 
Silvestre de Sacy and Caussin de Perceval were both in close contact with him and considered his description a worthy endeavor; they thus encouraged him to write an account in Arabic. ${ }^{204}$

Al-Tahtawi draws a distinction between 'ilm, fann, and $\sin _{\bar{a}} a$ in describing the contemporary French model of knowledge. The most important theoretical locus is al-Maqāla al-sādisa, al-faṣl al-awwal (essay 6, part 1), where he writes:

The French divide human knowledge into two categories: sciences ['ulüm] and arts [funūn]. Science [al-'ilm] consists of empirical knowledge, which is achieved by evidences, while art [al-fann] is the knowledge of making $[\sin \bar{a} a]$ something by specific rules... As for the arts, these are divided into intellectual arts and practical arts. The intellectual arts are those that are closest to the sciences, as the science of eloquence and rhetoric, the science of grammar, logic, poetry, drawing, sculpture [nahhäta], and music. These are the intellectual arts because they require scientific rules. As for the practical arts, these are the crafts. This is the classification of the French scholars. But in our use, in general, sciences and arts are one thing. There is a difference only between the being of art [kawn al-fann] as an independent knowledge [ ${ }^{i} \mathrm{im}$ ] in itself and as a tool for others. ${ }^{205}$

This is the first time, to the best of my knowledge, that the new European concept of (intellectual/fine) art as an independent category is explained in Arabic. It is perfectly translated since it is not the word, but the place of the concept in the contemporary Western European hierarchy of meaning that is rendered. It is also worth noting that al-Tahtawi, a well-trained young sheikh, is very familiar with, and reflects on, the fact that in the classical-medieval Arabic tradition there was not such a clear distinction between the arts and sciences.

He describes special (French) arts in terms of both theory and practice. As for his methods, when a word is too foreign, or when he simply wants to provide his reader with the original term, he transliterates those words phonetically, according to the rules of Arabic. For instance, the word "opera" becomes "al-ūbirā." 206 Al-Tahtawi also mentions ballet in connection with the opera. He says that in general dance is fann min al-funūn (an art of the arts) in France and remarks "that [for the French] it seems it is a kind of gorgeous thing, not sinful." ${ }^{207}$ As we have seen, raqs (dance) was not regarded as a fann in the traditional Arabic texts I surveyed. This appearance of fann in connection with ballet and social dance, a truly European created artistic phenomenon, represents the first time that that word is used to translate a specific type of (Western European) art.

Thus, based on his theoretical rendering and practical descriptions of the French arts, one might credit alTahtawi with the application of fann to the European (specifically French) concept of "art" as opposed to "science."

I would like to add three further remarks. First, since, as mentioned earlier, Bochtor's dictionary was published in 1828, during al-Tahtawi's stay in Paris (1826-31), it is hard to believe that it had no influence on him or vice versa, although so far I have not found any proof to support this supposition. Surely he was on good terms with Caussin de Perceval, the co-author of that dictionary.

Second, I believe that al-Tahtawi chose the word fann precisely because of its status as an elegant, charming (zarif) ars, and because shi $r$ (poetry), as a fann, was not regarded as religious. Both are connected to $a d a b$. Since 'ilm and șinā' $a$, and even șan' $a$, were used in Arabic for other specific purposes, fann was the only word available whose semantics would intersect with the then current French usage of "art." This is a hypothesis that needs further investigation.

Third, despite the later popularity of al-Tahtawi's book, it would be too hasty to believe that his translation and theoretical work immediately resulted in the canonization of this word. As I have shown, although "art" was already among the meanings of fann, for the artistic meaning of "art" the terms șinā'a and șan'a were still used in many later dictionaries (cf. those of alBustani, Biberstein-Kazimirski, and Belot, which were discussed earlier). Only a comparative lexicographical investigation of nineteenth-century Arab and Ottoman Turkish travelers' texts will reveal what other words travelers used to translate these concepts when they encountered the institutions and genres of European art. $^{208}$

Another famous personality was the Maronite Christian Ahmad Faris al-Shidyaq (d. 1887), who first converted to Protestantism and later became a Muslim. ${ }^{209}$ In al-Wāsița fì ma'rifat aḥwāl Mālița (The Device for 
the Knowledge of the Manners and Customs of Malta), published in 1836, and Kashf al-mukhabbä 'an funūn Urübba (The Unveiling of the Secrets of the Arts of Europe), ${ }^{210}$ published in 1854, al-Shidyaq described European arts and invented new Arabic words using three linguistic methods: pure invention (istinbātț), Arabization $\left(\operatorname{ta}^{\prime} \mathrm{r}^{\mathrm{i}} \mathrm{b}\right)$, and the application of old words for new meanings $\left(i h y \bar{a}^{\prime}\right){ }^{211} \mathrm{He}$ might have known al-Tahtawi from the time he spent in Egypt (between 1825 and 1834), and most probably read his book as well.

In his notes about Malta, he calls theatrical acting a hirfa (craft/profession), ${ }^{212}$ and devotes one chapter to music. ${ }^{213}$ Al-Shidyaq first underlines that fann al-mūsìqa was regarded as a branch of logic in some Arabic philosophers' works. He then compares European (i.e., French and Italian) songs with Arabic melodies. ${ }^{214} \mathrm{He}$ consequently uses the word fann for music in this chapter, but perhaps implies that it is a "branch" of the sciences.

Apropos visual culture, when speaking about Brunelleschi and Giotto in Kashfal-mukhabbā (his travels in England and France in the 1840s), al-Shidyaq uses the word șan'a: "the first who revived the art of carving sculptures was Brunelleschi, while Giotto was celebrated in painting" (awwal man ahyā șan'a naqr al-tamāthīl Brunelleschi wa kān Giotto nabihān fī tașwir $).{ }^{215} \mathrm{Al}$-Shidyaq did not use the word fann in connection with the European visual arts, but most probably followed the Ottoman Turkish model of șan'at, unlike the Azhar-educated al-Tahtawi.

In the 1840s, the Lebanese-Syrian doctor Mikha'il Mushaqa/Mishaqa (d. 1888) 216 $^{16}$ wrote a book on music that was left in manuscript form for decades (though its English translation was published in 1847, it was not printed in Arabic until 1899). ${ }^{217}$ In it, he reaches back to the medieval Arabic understanding of music: "Music is one of the exact sciences, from the branch of natural knowledge (Physics). It is a craft/science $\left(\sin ^{-} a\right) .{ }^{\prime 2} 18$ Nonetheless, he also uses the expressions fann al-tarb and fann al-mūsīq $\bar{a},{ }^{219}$ and variously refers to music as $a l-\sin ^{\prime} a$ and $a l-f a n n$. This also convincingly demonstrates that despite al-Tahtawi's use of fann, and his pathbreaking role in many other aspects as well, the lexicographic and popular canonization of fann was a long process in Arabic. In this, the role of the early Arabic press was crucial.
The Arabic Press

In the early public dissemination of "art," of particular interest are the following Arabic journals that appeared prior to 1876 , the year when al-Ahräm began publication: al-Waqä'i al-Mișriyya (Cairo/Bulaq, 1828), Hadìqat al-akhbār (Beirut, 1858), Nafīr sūriyya (1860, Beirut), al-Jawā'ib (Istanbul, 1861), Wādī al-Nīl (Cairo, 1867), Nuzhat al-afkār (Cairo, 1869), al-Janna (Beirut, 1870), al-Jinān (Beirut, 1870), Rawdat al-madāris al-Mișriyya (Cairo, 1870), Thamarāt al-funūn (Beirut, 1874), and Rawdat al-Akhbār (Cairo, 1874). The Ottoman Turkish press of the same period is richer, and most likely exercised a certain influence on the Arabic press. For instance, one of the first Ottoman journals, Takvīm-i Vekāyyi (Taqwīm-i Waqā'í, 1832), regularly contained a section entitled Fünūn (Funūn), in which new books were announced and poems, linguistic issues, and scientific news were printed.

The most important early Arabic cultural magazine was $W \bar{a} d \bar{l}$ al-Nìl, of which only three volumes (those from 1869,1870 , and 1871) have survived. It was under the direction of the remarkable Abu 'l-Su'ud Effendi, and on its title page it carried a slogan alluding to and reviving al-Ibshihi's literary compilation from the fifteenth century, al-Mustațaf fì kull fann mustazraf, which was discussed earlier (fig. 1).

The journal $W \bar{a} d \bar{\imath}$ al-Nìl also made a distinction between different kinds of information, advertising itself as an "Egyptian national ${ }^{220}$ weekly-political, scientific, literary - commercial, industrial, agricultural"221 (șahīfa ahliyya Mișriyya usbū'iyya-siyāsiyya, 'ilmiyya, adabiyya-tijāriyya, șinā'iyya, zirā'iyya). The choice to use al-Ibshihi's title as a slogan and to separate politics, science, and $a d a b$ from commerce, industry, and agriculture reflects a new type of classification of knowledge via the repository of medieval Arabic traditions mixed with contemporary European classification.

The editors also wrote about theater and opera but more or less understood "art" as adab, now considered to mean amusing literature: a section entitled Mawādd 'ilmiyya wa-niqāt adabiyya (Scientific materials and entertaining literary remarks) included poems, a treatise on modern agriculture (translated from the French), parts of a history of commerce (from the Italian), and an introduction/catalogue to the Egyptian Museum 


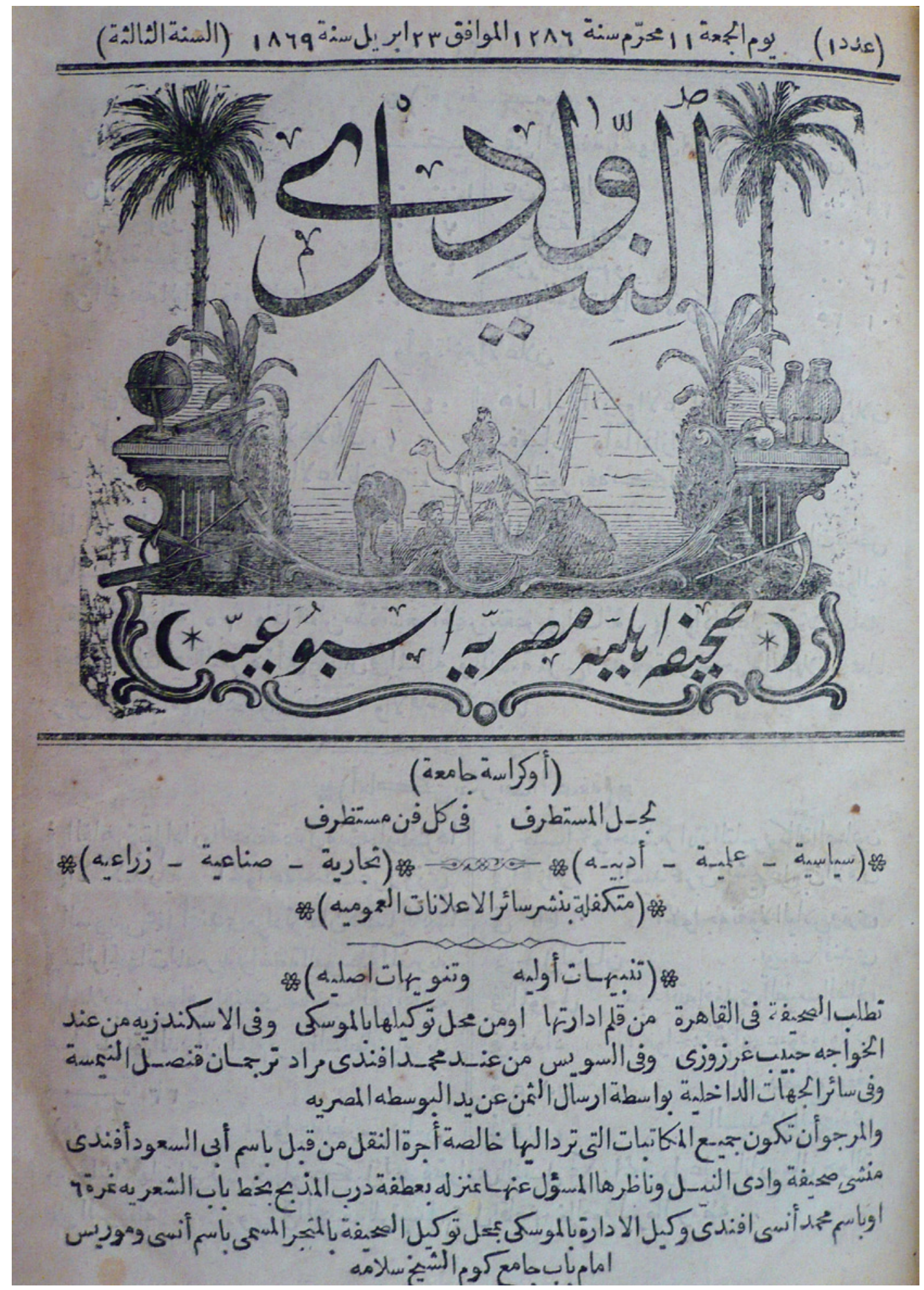

Fig. 1. Title page of Wādĩ al-Nìl 3, 1 (11 Muharram 1286 [April 23, 1869]). La Bibliothèque de l'Institut dominicain d'Études orientales, Cairo. (Photo: Adam Mestyan) 
(al-Antīqa-khāna al-Khidīwiyya [The Khedival Museum]) by August Mariette entitled Furjat al-mutafarrij (The Pleasure of the Spectator) in the Arabic translation by Abu 'l-Su'ud Effendi. ${ }^{22}$

This last piece is of particular importance since it was the first time that detailed descriptions providing the French perspective on ancient Egyptian sculptures were presented to the Arab public in Arabic. Mariette specifically wrote this catalogue for an Egyptian audience. ${ }^{223}$ Although this work needs to be thoroughly researched and analyzed, I have so far not found the word fann in it -only the phrases al-āthār al-jamī ${ }^{224}$ and al-āthār al-fakhima, ${ }^{225}$ which might be the translation of the French "oeuvre d'art" and also reflect the contemporary Ottoman Turkish usage. Unfortunately, the French original has not yet been identified; it may perhaps remain only in manuscript form.

One must note, however, that every issue of $W \bar{a} d \bar{\imath}$ al-Nìl contained a part of an edited medieval Arabic book, thus echoing the practices of European Orientalists, who privileged medieval texts over contemporaneous ones. (At the same time, Wādì al-Nìl also regularly published train timetables and ticket prices.) It might be said that this journal was the first attempt in Egypt to preserve the knowledge and traditions of the medieval Muslim/Arab sciences while at the same time enriching them with the contemporary European sciences and arts (?) within the same framework in Arabic.

The real popularization of fann as "art" for a wide readership and in a more and more canonized form in the Egyptian Arabic press starts in the 1880s. An 1884 article in al-Ahrām (Alexandria, 1876) about a new Arab theater group mentions that in the play "the actors enriched the acting with all kinds of sophisticated art" (tafannana al-mumaththilün bi 'l-tamthīl kull tafannun). ${ }^{226}$ Yet the journal used the expression al-funūn al-sharqiyya for "Orientalist sciences" in a report about the Orientalist Congress in Vienna in 1886. ${ }^{227}$ Even later, in an article from 1891, the expression fann al-tamthī ${ }^{228}$ is found in the sense of "art of acting," though one might argue that al-fann al-tamthìl ì rather signified the concept of art in its entirety.

As for the visual arts, in 1887 an essay entitled "al-Funūn al-jamila,"229 appeared in the monthly scientific journal al-Muqtataf (published first in Beirut and later in Cairo). In this article, Ahmad Fahmi, who was a member of a student mission sent to Paris to study at the École des Beaux-Arts, treats the "beaux arts" from a theoretical perspective in Arabic. Fahmi connects the arts and sciences to civilization and modernity ${ }^{230}$ and says: "there is no word which causes more disagreement in its philosophical definition and of which opinions could be more diverse than 'art' [al-fann]."231 This sentence clearly shows an already canonized usage of fann.

Fahmi cites d'Alembert (the philosopher and editor of the great Encyclopédie, d. 1783) and presents a (French?) classification of the sciences and the arts. The first overarching category is al-funun al-badaniyya (the physical crafts, which are connected to nature, such as agriculture). It has two branches: al-funūn al-șināi iyya (here mechanical arts, such as photography and lithography) and al-funūn al-yadiyya (handicrafts, such as the works of a goldsmith). The second overarching category is al-funūn al-'aqliyya (intellectual arts-the products of thinking and imagination) and it, too, has two branches: one (without a name) is that which needs only the intellect, such as grammar, while the other is al-funūn al-jamìla, "fine arts," which "need the intellect and sensations/emotions [hawās] at the same time." The latter has two further branches, the "arts of the voice" (sawtī), such as poetry and music, and the "arts of drawing" (rasmī), such as sculpture and painting. ${ }^{232}$ According to Shaw, only two years later, in 1889 , similar explanations of art were published in Ottoman Turkish, by Abdülhalim Memduh in the journal Muhit ț and by Mahmud Esad in his book on the history of art (Tärīhli Șanāyi). ${ }^{233}$

The literary and artistic output of Arab artists of the 1880 s and $1890 \mathrm{~s}^{234}$ signaled the full blossoming of the "cultural revival" known in Arabic as the Nahda, in which globalized concepts were negotiated, appropriated, or reevaluated, producing new types of works of art.

\section{CONCLUSION}

In the earliest Arabic lexicographical entries, fann had a wide semantic field (in the sense of "kind, branch") that is still retained today in Modern Standard Arabic. Later medieval Arabic dictionaries register some new 
derivatives with new meanings, such as "ornamentation," but it is only in the nineteenth century that fann is connected to knowledge/crafts in al-Bustani's dictionary.

In its non-lexicographical usages, the tradition of calling the genres of poetry funūn intersected with the custom among tenth-century intellectuals of also referring to the Neo-Platonic system of sciences as funūn (in the sense of branches of knowledge), resulting in a metonymy according to which fann acquired the meanings "science, ars, art, craft." In the case of poetry (which was a fann in the sciences and a type of scholarship), the words $\sin ^{-} \bar{a}^{\prime} a$ and fann were used interchangeably. Yet fann acquired a plurality of meanings.

From the fifteenth century onwards, șinā'at and mostly șan'at were used in Ottoman Turkish and Persian to denote a creative expression in the form of a beautiful work, principally in connection with the visual arts and architecture. In Arabic, this meaning was rather attached to poetry and $a d a b$, the arts of elegant behavior. Fann became the word used for these arts and was associated with the concept of the zariff, an elegant and witty gentleman.

Thus, nineteenth-century European and non-European dictionaries employed both words (fann and șinā'a/șan'a) in reference to "art," with slightly different meanings. It is in Bochtor and Caussin de Perceval's dictionary published in 1828 that fann appeared on its own in the meaning of "art, craft." Two years later, al-Tahtawi used fann in the Western European sense of art (via French) as an independent knowledge that had both practical and theoretical dimensions. He was, consequently, the first one to translate into Arabic the Western European (in this case, particularly French) concept of art. The word fann was transported from the field of poetry/adab in order to denote also the visual and the performative arts.

However, various factors have to be taken into consideration for the canonization of the word fann as art. First is the influence of Ottoman Turkish on nineteenth-century Arabic and șan'at as a rival word. More studies are needed on the exact relationship between nineteenth-century Arabic and Ottoman Turkish in order to determine the scope of the interplay between the two languages, not to mention earlier interactions.
Second, education and administration should be investigated more deeply as institutions that were conduits for new concepts and sometimes vehicles of cultural colonization. Comparative studies of Ottoman Turkish, Persian, and Arabic art education in the nineteenth century would perhaps reveal both the theoretical transformation and the effect of "art" as it related to the public sphere and social change. From this point of view, Ottoman Turkish soldier-painters and their schools are crucial, since this was where some of the early Arab painters were also trained, ${ }^{235}$ not to mention late nineteenth-century Ottoman Turkish and Ottoman Armenian painters. ${ }^{236}$

Third, the early Arab press is highly important, as it provided the Arabic-speaking public with a venue in which to discuss and negotiate the exact usages of words and concepts. In this regard, it can be said that the real canonization of fann started only in the 1880s in the Egyptian and Lebanese-Syrian press.

Almost all the nineteenth-century translators made use of the Arabic/Ottoman Turkish/Persian mixed cultural heritage as a continuous reference, even if they were ethnically Greeks, Armenians, or Copts. This is most obvious in the case of Egyptian Arabs and the journal Wādi al-Nìl making use of the fann zarîf tradition. Yet one might add that while șan'at in Ottoman Turkish was connected to the visual arts, in Arabic fann was instead associated with literary types of knowledge. Thus, the history of fann is of central importance for the study of the Nahda, the Arab renewal.

\section{History Department \\ Central European University, Budapest}

\section{NOTES}

Author's note: As my knowledge is lacking, at different stages of my research, I was grateful to take advantage of the expertise and suggestions of Kutlu Akalın, Islam Dayeh, Tamás Iványi, Miklós Maróth, Sándor Radnóti, Zsolt Simon, Zoltán Szombathy, László Tüske, Máté Veres, Stefan Weber, and an anonymous expert in Persian. I especially wish to thank Ola Seif, for the rare book she sent to me; Kinga Dévényi, for the comments she offered on the second version of the manuscript; Gülru Necipoğlu, for her critical remarks; the anonymous Muqarnas reviewer, for providing some very helpful and most patient criticism; and Karen Leal, for her careful editing. However, I alone am responsible for any 
errors in this article. All translations are mine unless otherwise indicated.

1. Paul Oskar Kristaller, “The Modern System of Arts: A Study in the History of Aesthetics I," Journal of the History of Ideas 12, 4 (1951): 498.

2. In my view, the creation of the "public" and publicity was due not only to the Lesenwelt (the readers' community, i.e., the world of letters) famously proposed by Jürgen Habermas but also to the "viewers' community," which was definitely already in existence in the eighteenth century. Jürgen Habermas, The Structural Transformation of the Public Sphere: An Inquiry into a Category of Bourgeois Society, trans. Thomas Burger (Cambridge, Mass.: MIT Press, 1989 [orig. pub. in German, 1962]), 51.

3. Venetia Porter, Word into Art: Artists of the Modern Middle East (London: British Museum Press, 2006). See my review of the exhibition: Mestyán Ádám, "Íráskép?" ("Written Image?”) Balkon 10 (2006): 32-38. Cf. also Nabil Naoum, Textes sur images: Art contemporain arabe (exhibition catalogue) (Paris: Acr Edition, Institut du Monde Arabe, 2000).

4. “Fann," http://ar.wikipedia.org/wiki/\%D9\%81\%D9\%86, last accessed December 7, 2009.

5. Silvia Naef, À la recherche d'une modernité arabe: L'évolution des arts plastiques en Egypte, au Liban et en Irak (Geneva: Editions Slatkine, 1996), 299-319.

6. Wijdan Ali, Modern Islamic Art: Development and Continuity (Gainesville, Fla.: University Press of Florida, 1997), 2.

7. Wendy M. K. Shaw, Ottoman Painting: Reflections of Western Art from the Ottoman Empire to the Turkish Republic (London: I. B. Tauris, 2011), 1-3.

8. Ahmad Y. Ghabin, "The Qur'anic Verses as a Source for Legitimacy or Illegitimacy of the Arts in Islam," Der Islam 75 (1998): 193-225.

9. Certainly there were discourses in Arabic about beauty, of both the human and literary kind. Today there is a trend to regard these texts as a pool of "aesthetics" that is usually translated as 'ilm al-jamāl (the science of beauty). Cf. S. Kahwaji, Encyclopaedia of Islam, New Edition (henceforth EI2) (Leiden, 1954-2004), s.v. "Ilm al-jamāl." Against these anachronistic tendencies, a great introduction to actual approaches to beauty in early Arabic discourses is Doris Behrens-Abouseif, Beauty in Arabic Culture (Princeton, N.J.: Markus Wiener Publishers, 1999).

10. For instance, Serpil Bağc1, "From Translated Word to Translated Image: The Illustrated Şehnâme-i Türkî Copies," Muqarnas 17 (2000): 162-76.

11. Cf. a methodologically very dubious work: Oliver Leaman, Islamic Aesthetics: An Introduction (Edinburgh: Edinburgh University Press, 2004). Rather thought-provoking are Valérie Gonzalez, Beauty and Islam: Aesthetics in Islamic Art and Architecture (London: I. B. Tauris Publishers, 2001); Behrens-Abouseif, Beauty in Arabic Culture; Bernard O'Kane, "Poetry, Geometry and the Arabesque: Notes on Timurid Aesthetics," Annales Islamologiques 26 (1992):
63-78; Gülru Necipoğlu, "L’idée de décor dans les régimes de visualité islamiques," in Purs Décors? Arts de l'Islam, regards du XIXe siècle: Collections des Arts Décoratifs, ed. Rémi Labrusse (Paris: Musée du Louvre, 2007), 10-23 (with notes); David J. Roxburgh, Prefacing the Image: The Writing of Art History in Sixteenth-Century Iran (Leiden: Brill, 2001).

12. Behrens-Abouseif, Beauty in Arabic Culture, 181.

13. Gülru Necipoğlu, The Age of Sinan: Architectural Culture in the Ottoman Empire (Princeton, N.J.: Princeton University Press, 2005), 135.

14. Kristaller, "Modern System of Arts I," 525-26, traces it back to the late seventeenth-century Debate between the Ancients and the Moderns (Querelle des Anciens et des Modernes).

15. J. Sourdel-Thomine, EI2, s.v. "Fann," emphasizes that "fann is the (modern) Arabic name for art."

16. Kristaller, "Modern System of Arts I," 498-99. Note that the idea of "making" is not found in the original meaning of the Latin term ars - it is only there because ars is used as the translation of techne.

17. It is worth briefly outlining two problems. First, the transmission of philosophical texts written in Greek into Arabic was a complicated process that was facilitated primarily by Syrian and Iraqi Christians such as Qusta ibn Luqa (d. ca. 913), Hunayn ibn Ishaq (d. ca. 877), and Thabit ibn Qurra (d. 901), who knew Greek well and tried to collect as many Greek manuscripts as they could in order to compare them with the existing Syriac or Arabic translations: Franz Rosenthal, The Classical Heritage in Islam, trans. Emile and Jenny Marmorstein (London and New York: Routledge, 1992 [orig. pub. in German, 1965]), 7, and 19-20, where Hunayn ibn Ishaq is quoted on his translation method. It is an open question whether Greek terms were always translated into Arabic with the help of the already existing Syriac terms. Surely some of the texts were translated "through a Syriac intermediary": F. E. Peters, Aristotle and the Arabs: The Aristotelian Tradition in Islam (New York: New York University Press, 1968), 63. Yet it is not likely that techne, for example, was translated with the help of a Syriac word, since the Syriac term used for techne was actually teknā. Even so, Thabit ibn Qurra simply used $\sin _{\bar{a}}{ }^{\mathrm{a}} a$ for techne, without having a Syriac version of the Arithmetics of Nichomachus of Gerasa: Kitāb al-Madkhal ilā 'ilm al-'adad, ed. Wilhelm Kutsch (Beirut: Imprimerie Catholique, 1959), 11. See more on this in the section on " $S$ - $n$-' as craft/knowledge/art." The second problem is that the translated texts can be characterized as Neo-Platonic, even in the case of Aristotle, since all his translated commentaries were of Neo-Platonic origins: Cristina d'Ancona, "Greek into Arabic: Neoplatonism in Translation," in The Cambridge Companion to Arabic Philosophy, ed. Peter Adamson and Richard C. Taylor (Cambridge: Cambridge University Press, 2005), 10-31.

18. Cf. the entry on "fann" also in Edward William Lane, An Arabic-English Lexicon, Derived from the Best and the Most 
Copious Eastern Sources, 8 vols. (Beirut: Librairie du Liban, 1968 [repr. of the original ed. (London: Williams and Norgate, 1863-93)]), 6:2446-48.

19. There are five opinions on this matter: 1) Al-Layth was the author; 2) Al-Khalil started it while al-Layth completed it; 3) Al-Khalil made an outline of the plan of the book that was followed by others; 4) Al-Khalil only suggested the idea, and others did the work; 5) Al-Khalil authored the work (Brockelmann shares this opinion, as does Sellheim). Cf. Yusrī 'Abd al-Ghanī 'Abd Allāh, Mu'jam al-ma'ājim al-'Arabiyya (Beirut: Dār al-Jīl, 1991), 88-89, and R. Sellheim, EI2, s.v. "al-Khalīl b. Ahmad." In his Arabic Grammar in Its Formative Age: Kitāb al-'Ayn and Its Attribution to Halīl b. Ahmad (Leiden: Brill, 1997), 116, Rafael Talmon established that all we know about the relationship between al-Layth and al-Khalil originates from the Kitāb al-'Ayn itself. Recently, Gregor Schoeler emphasized that although al-Khalil certainly did not write the book (this is the opinion of medieval Arab scholars as well), he can still be regarded as its intellectual creator, since he was the one who started its compilation. Gregor Schoeler, The Oral and the Written in Early Islam (London and New York: Routledge, 2006), 51-52 and 142-63.

20. Abū 'Abd al-Raḥmān al-Khalīl b. Aḥmad al-Farāhīdī, Kitāb al-'Ayn, ed. Mahdī al-Makhzūmī and Ibrāhīm al-Sāmarrā'ī, 8 vols. (Beirut: Mu’assasat al-Álamī li 'l-Mațbūāàt, 1988), 8:371-72.

21. M. G. Carter, "Arabic Lexicography," in Religion, Learning, and Science in the 'Abbasid Period, ed. M. J. L. Young, J. D. Latham, and R. B. Serjeant, The Cambridge History of Arabic Literature (Cambridge: Cambridge University Press, 1990), 106-17, at 111 .

22. 'Ikrima is one of the "successors," a highly regarded transmitter of hadith. Cf. J. Schacht, EI2, s.v. "Ikrima."

23. Cf. Sura 55 (al-Rahmān [The Beneficent]): 46-48: "But for he who fears the position of his Lord are two gardens. So which of the favors of your Lord would you deny? [The two gardens] having [spreading] branches" (i.e., the walls are the walls of the gardens).

24. Abu 'l-Haytham b. al-Razi (d. 841) was a grammarian and lexicographer.

25. Al-Qasim b. Sallam b. 'Abd Allah Abu 'Ubayd (d. 838), a famous grammarian and hadith scholar.

26. Abū Manșūr Muḥammad b. Aḥmad al-Azharī, Ṭahdhīb al-lugha, 15 vols. (Cairo: Dār al-Kitāb al-'Arabī, 1964-67), $15: 465$. The entry on fann in this dictionary is rather long, containing poems and hadith quotations; I thus selected only the relevant information.

27. "Unmöglich, wenn Yāqūt (Irshād VI, 419) tatsächlich ein Autograph des K. al-Ṣihāạ vom Jahre 396 H. gesehen hat.” Fuad Sezgin, Geschichte des arabischen Schrifttums (Leiden: Brill, 1967-), 8:215 n. 1.

28. Abū Nașr Ismāīil b. Hammād al-Jawharī, Tāj al-lugha wa-șiḩăh al-'Arabiyya, ed. Aḥmad 'Abd al-Ghafūr 'Ațțār, 6 vols. (Cairo: Dār al-Kitāb al-'Arabī bi-Mișr, 1956), 6:2176.

29. H. Fleisch, EI2, s.v. "Ibn Fāris."
30. 'Abd al-Ghanī, Mu'jam al-ma'äjim, 227.

31. Abu 'l-Ḥusayn Aḥmad b. Fāris b. Zakarīyā b. Habīb al-Rāzī, Mujmal al-lugha, ed. Zahīr 'Abd al-Muhsin Sulțān (Baghdad: al-Jumhūriyya al-'Irāqiyya [Iraq]: Mu’assasat al-Risāla, 1986), 700 .

32. Jār Allāh Abu 'l-Qāsim Maḥmūd b. 'Umar b. Aḥmad al-Zamakhsharī, Asās al-balāgha, 2 vols. (Beirut: Dār alKutub al-Ilmiyya, 1998), 2:38. Cf. John A. Haywood, Arabic Lexicography: Its History, and Its Place in the General History of Lexicography (Leiden: Brill, 1965), 106-7.

33. G. Hazai, EI2, s.v. "al-Kāshgarī."

34. Maḥmūd b. al-Husayn b. Muhammad al-Kāshgharī, Dīwān lughāt al-Turk, 3 vols. (Istanbul: Matbaa-yi 'Amire, 133335 [1915-17]), and facsimile edition of the manuscript, Dīwān lughāt al-Turk (Ankara: Kültür Bakanlığı, 1990). Turkish translation: Maḥmūd al-Kāshgarī, Divanü Lûgatit-Türk Tercümesi, trans. Besim Atalay, 3 vols. (with index) (Ankara: Alâeddin Kıral Basımevi, 1939-41); English translation: Maḥmūd al-Kāshgarī, Compendium of the Turkic Dialects (Türk Şiveleri Lügatı = Dīvānü Lugāt-it-Türk), ed. and trans. Robert Dankoff, in collaboration with James Kelly, 3 vols., Sources of Oriental Languages and Literatures: Turkic Sources 7 (Duxbury, Mass.: Ş. Tekin, printed at the Harvard University Printing Office, 1982-85).

35. Al-Kāshgarī, Compendium of the Turkic Dialects, 1:184 and 355. It is possible, however, that al-Kashgari does use the word fann, though I did not find any example of this and since there is no Arabic index, it is hard to determine.

36. Wetzstein published at least the first three parts under this title: Maḥmūd ibn 'Umar Zamakhsharī, Kitāb Muqaddimat al-adab = Samachscharii Lexicon Arabicum Persicum: Ex Codicibus Manuscriptis Lipsiensibus, Oxoniensibus, Vindobonensi et Berolinensi, ed. Ioannes Godofredus Wetzstein (Leipzig: Barth, 1843-50). Cf. Haywood, Arabic Lexicography, 118-19. There is an Ottoman Turkish translation: Maḥmūd ibn 'Umar al-Zamakhsharī, Aqșa 'l-arab fī tarjamat muqaddimat al-adab (in modern Turkish romanization: Aksa'l-ereb fî tercemeti Mukaddimeti'l-edeb), 2 vols. (Istanbul [Constantinople]: Matbaa-yi 'Amire, 1313 [1895]). Both Wetzstein's edition and the Ottoman Turkish translation were generously made available as a PDF scan from the Open Collections Program of the Harvard Library.

37. See the Introduction of al-Zamakhsarī, Samachscharii Lexicon, 2.

38. Ibid., 80 .

39. Ibid., 220 .

40. Ibid., 18. One must also note that al-Zamakhshari does not take account of his Asās, where he cited afänīn al-kaläm.

41. J. W. Fück, EI2, s.v. "Ibn Manżūr." Fück refers to the Qāmūs as if it were the work of al-Jawhari (the author of the Sihnăh), yet its author was al-Firuzabadi, who lived and worked after Ibn Manzur's death. Thus, when Ibn Manzur refers in his introduction to al-Jawhari, he was thinking of the Sihạh (as he explicitly states on the next page). According to Fück, Ibn Manzur also used the Nihãya of al-Dhahabi, who, at least to my knowledge, produced no book under 
this title. Ibn Manzur mentions Ibn al-Athir al-Jazari, who wrote a Nihāya (Nihāya fì gharīb al-ḥadìth). Jamāl al-Dīn Abu 'l-Faḍl Muhammad b. Mukarram b. 'Alī b. Ahmad al-Anșārī al-Ifrīqī Ibn Manẓūr, Lisān al-'Arab, ed. 'Abd Allāh 'Alī al-Kabīr, Muḥammad Aḥmad Ḥasab Allāh, and Hāāshim Muḥammad al-Shādhilī, 6 vols. (Cairo: Dār al-Ma'ārif, [1981]), 1:11-12.

42. Ibn Manzūur, Lisān al-'Arab, 5:3475-3477.

43. H. Fleisch, EI2, s.v. "al-Fīrūzābādī."

44. Abū Țāhir Majd al-Dīn Muḥammad b. Ya qūb al-Fīrūzābādī al-Shīrāzī, al-Qāmūs al-muhịṭ wa 'l-qābūs al-wasìt al-jāmic li-mā dhahaba min al-'Arab shamațît, 4 vols. (Cairo: al-Hay'at al-Qawmiyyat al-'Amma li 'l-Kitāb, 1977-80 [repr. of the 1301 (1884) ed. of al-Mațba'at al-Amīriyya]), 4:252.

45. C. Brockelmann, EI2, s.v. "Muhammad Murtaḍā."

46. Muḥammad Murtaḍa al-Husaynī al-Zabīdī, Tāj al-'arūs min jawāhir al-Qāmūs, 40 vols. (Kuwait: Maṭba at Hukūmat al-Kuwayt, 1965-2001), 35:515-21.

47. See the section below entitled "Fann as sophisticated knowledge."

48. Buțrus al-Bustān̄ī, Muḥit al-muḥịt (Beirut: Maktabat Lubnān, 1983), 703.

49. See the section below on "Non-lexicographical usages (1820s-60s)."

50. Al-Khalīl, Kitāb al-'Ayn, 1:304-5.

51. Lane, An Arabic-English Lexicon, 4:1732-1735.

52. Al-Jawharī, Sịhāh, 3:1245-1246.

53. Al-Zamakhsharī, Asās al-balāgha, 431-32.

54. Al-Kāshgarī, Compendium of the Turkic Dialects, 1:95.

55. Al-Zamakhsarī, Samachscharii Lexicon, 180.

56. No new meanings are provided in the Lisān al-'Arab, al-Qāmūs al-muḥiț and Tāj al-'arūs. Ibn Manẓūr, Lisān al-'Arab, 4:2508; al-Fìrūzābādī, al-Qāmūs al-muhịiț, 3:5051; al-Zabīdi, Tāj al-'arūs, 21:363-77.

57. A. Ghabin, EI2, s.v. "Șināà."

58. Al-Bustānī, Muḥịt al-muhīț, 520.

59. Lidia Bettini, Encyclopaedia of Arabic Language and Linguistics, ed. Kees Versteegh (Leiden: Brill, 2006-9), s.v. "Mutarādif."

60. Entries on fann are not found in the following works: 'Abd al-Malik b. Qurayb al-Așma '̄ī, Mā ikhtalafat alfāzu-hu waittafaqat ma'ānì-hu (Damascus: Dār al-Fikr, 1987); Abū Hilāl al-'Askarī, al-Furūq al-lughawiyya (Cairo: Dār al-'Ilm wa 'l-Thaqāfa, 1998); Aḥmad ibn Yahya Tha'lab, Majālis Tha'lab (internet ed., PDF by www.al-mostafa.com).

61. Al-'Askarī, al-Furūq al-lughawiyya, 135.

62. There is an enlarged, modernized, and thus altered Lebanese edition: Muhammad A'lā ibn 'Alī al-Tahānawī, Mawsū'at kashshāf iștilāhāt al-funūn wa 'l-'ulūm = Encyclopaedia of Artistic and Scientific Terminology (Beirut: Librairie du Liban Publishers, 1996). It is characteristic that the original title was changed because funūn in the original meant "sciences," but today is used in opposition to "ulūm (meaning "sciences"). Although I checked this edition, too, I used another one: Muhammad 'Alī al-Fārūqī
al-Tahānawī, Kashshāf iștilāhāt al-funūn, 4 parts in 2 vols. (Cairo: al-Mu'assasa al-Mișriyya al-'Āmma li 'l-Ta'līf wa 'l-Tarjama wa 'l-Ṭiba'a wa 'l-Nashr, 1963-77, unfinished). In his introduction, al-Tahanawi used fann in several senses, at one point employing funūn and 'ulūm separately, but here they are instead synonyms. He also says that he arranged his book into two fanns, "one fann for the Arabic and one fann for the Persian expressions." In this sentence, fann means simply "part": al-Tahānawī, Kashshāf (Cairo ed.), 1:1-2.

63. Al-Tahānawī, Kashshāf(Cairo ed.), 2:4, 235-36.

64. See the section below entitled "Fann as sophisticated knowledge."

65. In this section, to facilitate the research, $\mathrm{I}$ in some cases used the online database of the al-Warraq website, www.alwaraq.com. However, Iverified every result in a printed edition of the book; thus, the references are given here according to those printed versions. If there was any discrepancy, I always gave preference to the printed material.

66. The first philologists, such as Abu Said 'Abd al-Malik b. Qurayb al-Asma'i (d. 831), prepared vocabulary lists of Bedouin words for the needs of the urban scholar: Carter, “Arabic Lexicography," 106.

67. Cf. the introduction of al-Khalīl, Kitāb al-'Ayn, 1:47: "Arāda an ta'rifa bi-hi al-'Arab fì ash'āri-hà wa-amthāli-hā wa-mukhāțibāti-hā." See Haywood, Arabic Lexicography, 28, for his translation of the Baghdad manuscript: "His aim was that through it the Arabs should be known through their poetry, proverbs, and discourse, in an unequivocal manner."

68. Nichomachus of Gerasa, Kitāb al-Madkhal ilā 'ilm al-'adad, 11.

69. Ricardus Hoche, Nichomachi Geraseni Pythagorei: Introductionis Arithmeticae Libri II. (Leipzig: B. G. Teubneri, 1866), 6.

70. Nichomachus of Gerasa, Kitāb al-Madkhal ilā 'ilm al-'adad, 14.

71. R. Rashed and R. Morelon, EI2, s.v. "Muhạmmad Thābit b. Qurra."

72. Elaheh Kheirandish, "Organizing Scientific Knowledge: The 'Mixed' Sciences in Early Classifications," in Organizing Knowledge: Encyclopaedic Activities in the Pre-EighteenthCentury Islamic World, ed. Gerhard Endress (Leiden: Brill, 2006), 149-50.

73. 'Abd al-Raḥmān al-Badawī, Arisțūțālīs: Fann al-shi'r (Beirut: Dār al-Thaqāfa, 1973).

74. For the difficulties in tracing the previous translations by Yahyā b. 'Adī or Ishāa b. Hunayn and the question of al-Kindi's translation, see ibid., 50-53.

75. Ibid., 198.

76. Al-Badawī, Arisțūțālīs: Fann al-shi'r, 161. Cf. Dimitri Gutas, "The Greek and Persian Background of Early Arabic Encyclopaedism," in Endress, Organizing Knowledge, 91-101, at 95 .

77. Al-Badawī, Arisțūțālīs: Fann al-shì r, 201.

78. Kristaller, "Modern System of Arts I," 498-99. 
79. Yet one must note that al-Badawi naturally uses the title Fann al-shi' $r$ as the modern title of the whole collection.

80. A. Arazi, EI2, s.v. "Shi'r."

81. Gerhard Endress, "The Cycle of Knowledge: Intellectual Traditions and Encyclopaedias of the Rational Sciences in Arabic-Islamic Hellenism," in Endress, Organizing Knowledge, 103-33, at 105.

82. Necipoğlu, "L'idée de décor," 11; Behrens-Abouseif, Beauty in Arabic Culture, 22, 37, 107.

83. Sheila S. Blair and Jonathan M. Bloom, "The Mirage of Islamic Art: Reflections on the Study of an Unwieldy Field," Art Bulletin 85, 1 (March 2003): 171.

84. Arazi, EI2, s.v. "Shi' r." See the section below entitled "Fann as sophisticated knowledge."

85. Proceedings of the conference "The Making and Reception of Painting in the Pre-Modern Islamic World," held at the Aga Khan Program for Islamic Architecture at Harvard University (May 1999), ed. David J. Roxburgh, Muqarnas 17 (2000).

86. Literature on Arabic, Persian, Ottoman Turkish, or "Islamic" calligraphy is abundant; among the most important works are those by Yasser Tabaa, Sheila Blair, Irene A. Bierman, and Estella Whelan.

87. Roxburgh, Prefacing the Image, 213, and glossary.

88. It is perhaps telling that in the online library of al-Warraq (www.alwaraq.net), the search for fann al-khatt did not produce any result, but fann al-kitāba is found in nineteen books. Compare this to șināat al-khatț (eleven results) and șināat al-kitāba (102 results in fifty books). Of course, the collection of al-Warraq is restricted and such an inquiry can always be misleading.

89. Necipoğlu, "L'idée de décor," 15 .

90. Mimar Sinan, Sinan's Autobiographies: Five Sixteenth-Century Texts, ed. and trans. Howard Crane and Esra Akın, with an introd. by Gülru Necipoğlu (Leiden: Brill, 2006).

91. San' $a t$ is rendered as "art" in the English translations: ibid., 66, 75, 91 (as God's art [craft]), 115, 118, 125, 131, 132. It must be noted that for some reason the majority of the occurrences of san'at are to be found in the lyrical parts of the text.

92. I follow here Crane and Akın's transliteration and transcription: Crane and Akın, Sinan's Autobiographies, 59 (English translation), 62 (transcription), and 419 (2b in facsimile).

93. Ibid., 120 (translation), 146 (transliteration), 534 (7a in facsimile).

94. The letter of the royal architect Ilyas to Sultan Murad III, dated 1589, uses the expression "binā [- 1 ] ' $i l m$." As quoted in Necipoğlu, Age of Sinan, 124.

95. See the section below on "Fann in the Nineteenth Century."

96. Crane and Akın, Sinan's Autobiographies, 74 (translation), 85 (transcription), 441 (13b in facsimile).

97. Ibid., 91 (translation), 104 (transcription), 482 (8a in facsimile).

98. Ibid., 118 (translation), 145 (transcription), 532 (5b in facsimile)
99. Ibid., 131 (translation), 156 (transcription), 551 (15b in facsimile).

100. Necipoğlu, "L’idée de décor," 15.

101. Roxburgh, Prefacing the Image, 107-8.

102. Ibid., 213-15.

103. For instance, there are numerous later copies of Sinan's autobiographies preserved in Cairo. Gülru Necipoğlu, "Preface," in Crane and Akın, Sinan's Autobiographies, xiv.

104. Necipoğlu, Age of Sinan, 135-47, esp. on Sinan's and contemporary concepts about architecture.

105. Cafer Efendi, Risāle-i Mímāriyye: An Early SeventeenthCentury Ottoman Treatise on Architecture, trans. Howard Crane (Leiden: E. J. Brill, 1987), 31 (16v in the facsimile).

106. Ibid., $96-97$ ( $78 \mathrm{v}$ in the facsimile).

107. Shaw, Ottoman Painting, 119-21.

108. Arazi, EI2, s.v. "Shi'r."

109. Li 'l-shi'r șinā'a wa-thaqāfa ya'rifu-hā ahl al-'ilm ka-sā'ir așnāf al-'ilm wa 'l-șinā'ät min-hā mā tathqafu-hu al-'ayn wa-min-hā mà tathqafu-hu al-udhn wa-min-hā mā tathqafu-hu al-yad wa-min-hā mā tathqafu-hu al-lisān. Muhạmmad b. Sallām al-Jumahī, Ṭabaqāt al-shu'arā', ed. Joseph Hell (Leiden: Brill, 1916), 3. Cf. the critical edition: Muhạmmad b. Sallām al-Jumahịi, Ṭabaqāt fuhūl al-shu'arā', ed. Maḥmūd Muhammad Shākir (Cairo: Dār al-Maāāif li 'l-Tibā'a wa 'l-Nashr, 1952), 6. Rina Drory translated this opening passage in the following manner: "In poetry there is a kind of professional knowledge (sina'a, skill, techne as in Greek philosophy), which only its possessors recognize, just as is the case with other types of knowledge and in other professions like occupations which require keenness of the eye, the ear, the hand or the tongue." Drory did not draw a distinction between $\sin _{\bar{a}}{ }^{\prime} a$ and thaqäfa. Rina Drory, "The Abbasid Construction of the Jahiliyya: Cultural Authority in the Making," Studia Islamica 83 (1996): 33-49, at 45.

110. Abu 'l-Faraj al-Ișfahānī, Kitāb al-Aghānī, 24 vols. (Cairo: Dār al-Kutub al-Mișriyya [various publishers], 1927-74), 10:69. San' $a$ as a verb in the sense of "composing poetry" is found in numerous places of al-Isfahani's work: one might say that this is the verb that signified composing poetry, in connection, for instance, with Ishaq b. Ibrahim, who made a sawt so beautiful that it surprised the Caliph al-Mu'tasim: al-Ișfahānī, Kitāb al-Aghānī, 5:417.

111. Arazi, EI2, s.v. "Shi'r."

112. Drory, "Abbasid Construction of the Jahiliyya," 44.

113. Gutas, "Greek and Persian Background," 91.

114. One reason is the already present "multiple traditions." Endress, "Cycle of Knowledge," 106.

115. Ibid., 116-17.

116. Among his teachers were Yahya b. 'Adi (a disciple of al-Farabi and Matta b. Yunus) and al-Sijistani (another disciple of Matta b. Yunus): Ibrahim Keilani, Abū Hayyān al-Tawhìdì: Essayiste arabe du IVe s. de l'Hégire (Xe s.); Introduction à son oeuvre (Beirut: Institut français de Damas, 1950), 22-23. Cf. S. M. Stern, EI2, s.v. "Abū Hayyān al-Tawhīdī"; Endress, "Cycle of Knowledge," 112-13. 
117. Abū Hayyān al-Tawhīdī, Kitāb al-Imtā' wa 'l-mu'ānasa, 3 pts. in 1 vol. (Beirut: Manshūrāt Dār Maktabat al-Hayāt, 1966), pt. 2, p. 70.

118. However, al-Tawhīdī has his own classification of sciences, known as the Risāla fi 'l-'ulūm.

119. Abū Hāmid al-Ghazālī, Ihyyà' 'ulūm al-dīn (Beirut: Dār al-Șādir, 2000).

120. Ibn Khaldūn, Muqaddimat Ibn Khaldūn, ed. 'Alī 'Abd al-Wāhịid al-Wāfī (Cairo: Dār Nahḍat Mișr, 1981), 1277.

121. See the section below entitled "Fann as sophisticated knowledge."

122. Al-Jumahī̄, Țabaqāt al-shu'arā' (Leiden, 1916), 18; al-Jumahīi, Ṭabaqāt fuhūl al-shu'arā' (Cairo, 1952), 54.

123. Al-Ișfahānī, Kitāb al-Aghānī, 2:157.

124. Cf. R. Jacobi, EI2, s.v. "Nasīb."

125. Al-Ișfahānī, Kitāb al-Aghānī, 9:109.

126. Abū Manșūr 'Abd al-Malik al-Tha'ālibī al-Nīsābūrī, Yatīmat al-dahr fì maḥāsin ahl al-'aṣr, 5 vols. (Beirut: Dār al-Kutub al-'Ilmiyya, 1983), 4:132.

127. Shahāb al-Dīn Muhammad b. Aḥmad al-Ibshīhī, al-Mustațraffì kull fann mustazraf (Beirut: Dār al-Maktabat al-Hayāt, 1988). For the difficulties in translating the title, see the section entitled "Fann as sophisticated knowledge."

128. Ibid., 210.

129. Kātib Çelebi, Kitāb Kashf al-zunūn 'an asāmī al-kutub wa 'l-funūn, 2 vols. (Beirut: Dār Ihyā' al-Turāth al-'Arabī, n.d. [orig. pub. Beirut: Maarıf Matbaası, 1941]), 2:1079.

130. Al-Nuwayrī, Nihāyat al-arab fī funūn al-adab, 2nd ed., 33 vols. (Cairo: Dār al-Kutub al-Mișriyya, 1929).

131. Ibid., 1:2-3.

132. One may argue that fann was already being used in this sense in the twelfth century, by religious scholars such as Ibn al-Jawzi. His work Funūn al-afnān fì 'uyūn 'ulūm $a l-Q u r^{\prime} \bar{a} n$ uses the expression in the title, though here it is still rather a metaphor for the diversity of topics concerning the sciences in the Koran rather than a reference to fixed fields of knowledge, based on the custom of giving playful titles. Different manuscripts give different titles: see the wonderful introduction of Hasan Diyä' al-Dīn 'Itr in Abū al-Faraj 'Abd al-Raḥmān ibn 'Alī Ibn Jawzì, Funūn al-afnān fí 'uyūn 'ulūm al-Qur'ān (Beirut: Dār al-Bashāìr al-Islāmiyya, 1987), 121-24.

133. Al-Ibshīhī, al-Musțatraf fì kull fann mustazraf, 1 .

134. Behrens-Abouseif, Beauty in Arabic Culture, 85-86.

135. Federico Corriente, A Dictionary of Andalusi Arabic (Leiden: Brill, 1997), s.v. "f-n-n."

136. Al-Tahānawī, Kashshāf (Cairo ed.), 1:1, 3-76.

137. See the section above on "S $n$-' as craft/knowledge/art."

138. Al-Zabīìi, Tāj al-'arūs, 1:2.

139. Ibid., 1:3.

140. O. Wright, EI2, s.v. "Mūsīqī."

141. Behrens-Abouseif, Beauty in Arabic Culture, 73-77.

142. The most cited criticism is that of Ibn Taymiyya, Kitāb al-Samā' wa 'l-raqș = Musique et danse selon Ibn Taymiyya, le livre du Samâ' et de la danse, compilé par le Shaykh Muhammad al-Manbijī, trans. and ed. Jean R. Michot
(Paris: J. Vrin, 1991). Cf. also Ibn Taymiyya's Fatāwā, or Ibn al-Jawzī in his Talbīs Iblìs. For the rich literature written in favor of samā', see J. During, EI2, s.v. "Samā'."

143. Ibn 'Arabī, Futūḥāt al-Makkiyya, 4 vols. (Cairo: Dār al-Kutub al-'Arabiyya al-Kubrā, 1911), 3:501 and 4:330 ("awwal 'ilm hasșala li 'l-'ālam bi-Allāh 'ilm al-samā bi 'l-īqā' min Allāh").

144. Wright, EI2, s.v. "Mūsīqī."

145. Ibn Nașr al-Fārābī, Ārā' ahl al-madīna al-fādila wa-mud̄àddātu-hā (Beirut: Dār Maktabat al-Hilāl, 1995), 135.

146. Ibn Sīnā, al-Shifä', 22 pts. in 10 vols. (Cairo: al-Mațáa al-Amīriyya, 1952), vol. 1, pt. 2, p. 184 (al-Mantiq-alMaqūlāt, al-Maqāla al-Khāmisa, Fașl al-Thālith).

147. Katib Çelebi, Kitāb Kashfal-zunūn, 1:16 and 1:911.

148. Suna Suner, "Of Messengers, Messages and Memoirs: Opera and the Eighteenth-Century Sefäretnāmes," unpublished paper given at the conference "Musical Societies and Politics: Ottoman and Early Republican Turkey in Its European Context," European University Institute, Florence, and Boğaziçi University, Istanbul, held at Boğaziçi University, October 29-31, 2009.

149. Such research is now being conducted by Suna Suner, who is currently working on this topic in the Don Juan Archive of Vienna. The latest Turkish publication is by Hasan Korkut, Osmanlı Elçileri Gözüyle Avrupa (Istanbul: GökkubbeBilimevi Basın Yayın, 2007).

150. Quoted in Nazariyyāt al-masrah (Theories of Theater), ed. Muhammad Kāmil al-Khațīb (Damascus: Manshūrāt Wizārat al-Thaqāfa, 1994), 13.

151. Nermin Menemencioğlu, "The Ottoman Theatre 18391923," Bulletin of the British Society for Middle Eastern Studies 10, 1 (1983): 48-58, at 49. Namik Sinan Turan and Ayşegül Komşuoğlu, "From Empire to the Republic: The Western Music Tradition and the Perception of Opera," International Journal of Turcologica, 2, 3 (2007): 7-31, at 12.

152. Menemencioğlu, "Ottoman Theatre"; Turan and Komşuoğlu, "From Empire to the Republic," 10. Cf. Metin And, A History of Theatre and Popular Entertainment in Turkey (Ankara: Forum Yayınları, 1963-64). For an introduction, see Esin Ulu, "The First Operatic Activities in Istanbul," Istanbul, 1, 2 (1993): 109-15.

153. Shaw, Ottoman Painting, 119.

154 "Mașdar bi-mainā 'l-'ilm [...] wa-'inda 'l-ahl al-'Arabiyya kalām yuqșad bi-hi 'l-wazn wa 'l-taqfiyya" (It is a verbal noun in the meaning of science/knowledge [...] it is used as an expression in the sense of poetic measure and rhyming by those who speak Arabic): al-Bustānī, Muhịt al-muhịt, 468 .

155. Jacobus Golius, Lexicon Arabico-Latinum: Contextum ex Probatioribus Orientis Lexicographis; Accedit index latinus copiosissimus qui lexici latino-arabici vicem explere possit (Lugduni Batavorum: Typis Bonaventurae \& Abrahami Elseviriorum, Prostant Amstelodami apud Johannem Janssonium, 1653). 
156. For some reason, Haywood says that Golius worked on the basis of the al-Qāmūs (J. Haywood, EI2, s.v. "Qāmūs"), but I did not find any evidence pointing to this in the copy I consulted. Golius says he mainly used the Sih indicated with a $G i$. in the text.

157. Golius, Lexicon, 1824-25. Of course, Golius also gives the various derivatives, such as finn, fanan, fannān, funna, tafnīn, etc., but I did not consider these here.

158. Ibid., 495.

159. Ibid., 599.

160. Ibid., 1385.

161. Ibid., 1438.

162. Ibid., 1437.

163. Georg Wilhelm Friedrich Freytag, Lexicon Arabico-Latinum ex Opere Suo Maiore in Usum Tironum Excerptum (Halle: Schwetschke et Filium, 1837), 481.

164. J. F. Ruphy, Dictionnaire abrégé françois-arabe: À l'usage de ceux qui se destinent au commerce du Levant (Paris: L'Imprimerie de la République, 1802), 12.

165. Don Raphaël de Monachis, Dizionario italiano e arabo, che contiene in succinto tutti i vocaboli che sono più in uso e più necessari per imparar a parlare le due lingue correttamente = Qāmūs Ițāliyānī wa- 'Arabì yatadamman bi 'l-ikhtișār kull al-alfāz al-hāài bi-hā al-'āda wa 'l-alzam li-ta' lìm al-kalām wa 'l-mafhūmiyyat al-lughatayn 'ala 'l-șah̄in wa-qad yuqassim ilā qismayn (Bulaq, 1822 [1238]), 28. The author (d. 1831) was professor of Arabic at the École des Langues orientales. Cf. P. C. Sadgrove, Encyclopedia of Arabic Literature, 2 vols., ed. Julie Scott Meisami and Paul Starkey (London: Routledge, 1998), s.v. "Zakhūr, Père Rufā̄îl."

166. Ibid., 239.

167. Ellious Bochtor, Dictionnaire français-arabe, revue et augmenté par A. Caussin de Perceval (Paris: Firmin Didot, 1828), 58. I am particularly grateful to the anonymous reviewer of Muqarnas for both this important suggestion and the reference.

168. In the fourth edition of Bochtor's dictionary (Paris: Librairie Firmin Diderot Frères, 1869), 57.

169. Alain Silvera, "The First Student Mission to France under Muhammad Ali," in Modern Egypt: Studies in Politics and Society, ed. Elie Kedourie and Sylvia G. Haim (London: Frank Cass, 1980), 1-19, at 10.

170. Bochtor, Dictionnaire, preface (4th ed. [1869]), page i.

171. Ibid.

172. Ibid., page ij.

173. Alexandre Handjéri, Dictionnaire français-arabe-persan et turc: Enrichi d'examples en langue turque avec des variantes, et de beaucoup de mots d'arts et des sciences, 2 pts. in 1 vol. (Moscow: Imprimerie de l'Université impériale, 1840-41), $1: 153$.

174. Ibid., 1:157.

175. [Anonymous], Dictionnaire français-arabe (Beirut: Imprimerie Catholique, 1857), 43-44.

176. Albert de Biberstein-Kazimirski, Dictionnaire arabefrançais, contenant toutes les racines de la langue arabe, leurs dérivés, tant dans l'idiome vulgaire que dans l'idiome littéral, ainsi que les dialectes d'Alger et de Maroc, 2 vols. (Paris: Maisonneuve, 1860), 1:1375-1377.
177. Ibid., 2:636

178. Reinhart Dozy, Supplément aux dictionnaires arabes, 2nd ed., 2 vols. (Leiden: Brill; Paris: Maisonneuve Frères, 1927 [orig. pub. 1877-81]), 2:283.

179. P. J-B. Belot, Dictionnaire français-arabe, 2 vols. (Beirut: Imprimerie Catholique, 1890), 1:73.

180. Habib Anthony Salmoné, An Advanced Learner's ArabicEnglish Dictionary (Beirut: Librairie du Liban, 1978 [orig. pub. 1889]), 723-24.

181. Edmund Fagnan, Additions aux dictionnaires arabes (Beirut: Libraire du Liban, 1923), 135.

182. Socrates Spiro, Arabic-English Dictionary of the Colloquial Arabic of Egypt, containing the vernacular idioms and expressions, slang phrases, vocables, etc., used by the native Egyptians (Beirut: Libraire du Liban, 1980 [repr. of the 1895 orig.]), 466.

183. J. W. Redhouse, Redhouse's Turkish Dictionary in Two Parts: English and Turkish and Turkish and English (London: Bernard Quaritch, 1880), 43.

184. Ibid., 682.

185. Şemseddin Sâmî (Ch. Samy-Bey Fraschery), Kamus-ı Fransevî: Türkçeden Fransızcaya Lugat = Dictionnaire turcfrançais (Constantinople: Mihran Matbaası, 1883), 782.

186. Ibid., 661.

187. Khaled Fahmy, All the Pasha's Men: Mehmed Ali, His Army, and the Making of Modern Egypt (Cairo and New York: American University in Cairo Press, 2002 [orig. pub. 1997]).

188. Muḥammad Sawā' ī, Azmat al-muștalah al- 'Arabì fi 'l-qarn al-tāsi' 'ashr (Beirut: Dār al-Gharb al-Islāmī, 1999), 73-76.

189. On the music schools of Muhammad 'Ali, see Adam Mestyan, "Muhammad 'Alī (Mehmed Ali) and European Music in Egypt (1805-1848)," in Ottoman Empire and European Theatre II, ed. Michael Hüttler (forthcoming, Vienna: DJA/Lit, 2011).

190. Especially daftars 3, 5, and 6 in the Collection 1/1/6M, Șādir, Dīwān al-Madāris al-Turkī, Dār al-Wathāi iq al-Qawmiyya (National Archives of Egypt, Cairo).

191. Stephen Paul Sheehi, "Inscribing the Arab Self: Butrus al-Bustānī and Paradigms of Subjective Reform," British Journal of Middle Eastern Studies 27, 1 (2000): 7-24.

192. Peter Avery, "Printing, the Press, and Literature in Modern Iran," in The Cambridge History of Iran, vol. 7, From Nadir Shah to the Islamic Republic, ed. Peter Avery, Gavin Hambly, and Charles Melville (Cambridge: Cambridge University Press, 1991), 815-69, at 823-24.

193. Ekmeleddin İhsanoğlu, Ottoman Educational Institutions during the Reform Period (Manchester: FSTC Limited, 2004), online: http://www.muslimheritage.com/uploads/ ReformOttomans.pdf.

194. Wijdan Ali, "Islamic Countries," in Modern Islamic Art, provides short outlines of art education. It is possible that new research will provide more data about nineteenthcentury Ottoman art education: see, for example, Shaw, Ottoman Painting.

195. For Donizetti Pasha, see Emre Arac1, Donizetti Paşa: Osmanlı Sarayının İtalyan Maestrosu (Istanbul: Yapı Kredi, 2006). 
196. For an overview, see Stanford J. Shaw and Ezel Kural Shaw, History of the Ottoman Empire and Modern Turkey, 2 vols. (Cambridge: Cambridge University Press, 1992 [1977]), 2:47-48.

197. Fatma Ürekli, İslâm Ansiklopedisi (Istanbul: Türkiye Diyanet Vakfi, 2009), s.v. "Sanāyi-i Nefīse Mektebi." Cf. Wendy M. K. Shaw, Possessors and Possessed: Museums, Archaeology, and the Visualization of History in the Late Ottoman Empire (Berkeley, Calif.: University of California Press, 2003), 99.

198. Shaw, Ottoman Painting, 66-75, about the first director, Osman Hamdi Bey.

199. Richard N. Verdery, "The Publications of the Bulaq Press under Muhammad 'Alī of Egypt," Journal of the American Oriental Society 91, 1 (1971): 129-32.

200. Letter dated February 1, 1850. HR.TO 410/66 (Nezaret Hariciyye, Tercüme Odası [Foreign Ministry, Office of Translation]), Başbakanlık Arşivleri: Osmanlı Arşivi (The Prime Ministry's Archives: Ottoman Archive), Istanbul, Turkey.

201. Jacques Tagher, "Pietro Avoscani, artiste-décorateur et homme d'affaires," Cahiers d'Histoire Égyptienne 4 (1949): 306-14. Cf. Philip Sadgrove, The Egyptian Theatre in the Nineteenth Century (1799-1882) (Cairo: American University of Cairo Press, 2007 [orig. pub. 1996]).

202. Rifāéa Rāfí al-Ṭahțāwī, al-Dìwān al-nafìs fì ìwān Bārīs, aw Takhlīṣ al-ibrīz fī talkhīṣ bāriz (Beirut: al-Mu'assasa al-'Arabiyya li 'l-Dirāsāt wa 'l-Nashr, 2002 [1834]). Cf. Mohammed Sawaie, "Rifa'a Rāfi' al-Ṭahțawi and His Contribution to the Lexical Development of Modern Literary Arabic," International Journal of Middle East Studies 32, 3 (2000): 395-410, and Sawā īî, Azmat al-muștalah, 123.

203. Al-Ṭahțāwī, al-Dīwān al-nafìs, 23.

204. Ibid., 206.

205. Ibid., 245-46. I was tempted to interpret the word innamā as "yet" in the last sentence, supposing that al-Tahtawi here adds his own reflection (i.e., "Yet, there is a difference between the being of art as an independent knowledge in itself and as a tool for others."). But in the previous German and English translations, innamā is translated as "nur" and "only," respectively, since the translators wanted to emphasize that this last sentence is connected to the previous one about arts and sciences. I followed these previous solutions because I believe that I cannot prove my point sufficiently. The sentence in question in the German translation: "Das ist die Einteilung der Europäischen Philosophen. Ansonsten sind 'ulūm - Wissenschaften - und funūn - Künste - bei uns zumeist ein und dasselbe, und man macht einen Unterschied nur insofern, ob eine Kunst ein selbständiges Wissensgebiet ist oder Hilfsmittel für etwas anderes.” Rifā'a al-Ṭahțāwī, Ein Muslim entdeckt Europa: Die Reise eines Ägypters im 19. Jahrhundert nach Paris, ed. Karl Stowasser (Leipzig und Weimar: Gustav Kiepenheuer Verlag, 1988), 234-35. In English: "Such is the division drawn up by Frankish scholars. However, in our country, there is very often no difference between sciences and arts; a distinction is made based only on whether an art is an independent science or serves as a tool for another." Rifa'a Rafi'
al-Tahtawi, An Imam in Paris: Al-Tahtawi's Visit to France (1826-1831), introd. and trans. Daniel L. Newman (London: Saqi Books, 2004), 331.

206. Al-Ṭahțāwī, al-Dīwān al-nafìs, 140.

207. Ibid., 143.

208. Such as the recently published memoires of three Algerian travellers, Sulaymān b. Șayyām, Ahmmad Walad Qād, and Muhammad b. al-Shaykh al-Faghūn al-Qusanțīnī, in Thalāth riḥlāt Jazā'iriyya ilā Bārīs, 1902, 1878, 1852, ed. Khālid Ziyādah (Beirut: al-Mu'assasa al-'Arabiyya li 'l-Dirāsāt wa 'l-Nashr, 2005), or the travels of Fransīs Fath Allāh al-Marrāsh, Riḥlat Bārīs, 1867 (Beirut: al-Mu'assasa al-'Arabiyya li 'l-Dirāsāt wa 'l-Nashr, 2004).

209. A. G. Karam, EI2, s.v. "Fāris al-Shidyāq."

210. These were published together as Aḥmad Fāris al-Shidyāq, al-Wāsița fì márifat aḥwāl Mālița wa-kashf al-mukhabbā 'an funūn Urūbbā, 1834-1857 (Beirut-Abu Dhabi: al-Mu'assasat al-'Arabiyya li 'l-Dirāsāt wa 'l-Nashr, 2004).

211. Sawā'ī, Azmat al-muștalaḥ, 99-113. Cf. Muhammad 'Alī al-Zarkān, Ajwānib al-lughawiyya 'inda Ahmad Fāris al-Shidyāq (Damascus: Dār al-Fikr, 1988), 351-55.

212. Al-Shidyāq, al-Wāsița, 55 .

213. Al-Shidyāq, al-Wāsița, 89-97. For an interpretation, cf. Pierre Cachia, “A Nineteenth-Century Arab's Observations on European Music,” Ethnomusicology 17, 1 (1973): 41-51.

214. Al-Shidyāq, al-Wāsița, 91-93.

215. Ibid., 320 .

216. Eckhard Neubauer states that his name should be transliterated as "Mushāqa" because Mashāqa/Mishāqa is the vernacular pronunciation. Eckhard Neubauer, "Arabic Writings on Music: Eighth to Nineteenth Centuries," The Garland Encyclopaedia of World Music, 10 vols. (London and New York: Routledge, 2002), 6:363-86, at 382. However, it seems Mishāqa is rather accepted. Fruma Zachs, "Mīkhāīl Mishāqa: The First Historian of Modern Syria," British Journal of Middle Eastern Studies 28, 1 (May, 2001): 67-87; Shireen Maalouf, "Mīkhāīl Mishāqa: Virtual Founder of the Twenty-Four Equal Quartertone Scale," Journal of the American Oriental Society 123, 4 (Oct.-Dec., 2003): 835-40.

217. Mīkhā'īl Mishāqa, al-Risāla al-shihābiyya fi 'l-șinā'a al-mūsiqiyya (Cairo: Dār al-Fikr al-'Arabī, 1996); cf. the introduction of the editor, İzīs Fath Allāh, page ta'. The 1899 edition was prepared at the Université Saint-Joseph in Beirut. The French translation is: P. L. Ronzevalle, "Un traité de musique arabe moderne," Mélanges de la Faculté Orientale (Université Saint-Joseph) 6 (1913): 1-68 (translation with the preface of the translator), and 69-120 (Arabic original with notes). The partial English translation from 1847 is by Eli Smith, "A Treatise on Arab Music, Chiefly from a Work by Mikhāil Meshākah, of Damascus," Journal of the American Oriental Society 1, 3 (1847): 171-217 (with an introduction by Smith).

218. Mishāqa, al-Risāla al-shihābiyya, 5. "Șināa” was translated by Ronzevalle as "art" in 1913. Ronzevalle, "Un traité de musique arabe moderne," 10 . Smith did not translate this first part (which perhaps did not exist at that time).

219. Mishāqa, al-Risāla al-shihābiyya, 113. 
220. Ahliyya could be translated also as "popular," "civic," "native," or "professional."

221. The earliest surviving copy of $W \bar{a} d \bar{l}$ al-Nìl is dated April 23, 1869 (11 Muharram 1286)-I quote the title page here. The latest extant issue is from March 24, 1871. It surely began publication in 1866, since 1869 (1286) was its third yearly ( $h i j r \bar{i})$ volume.

222. The catalogue was published in installments in the journal $W \bar{d} \bar{d}$ al-Nìl throughout the summer of 1869 , in preparation for the Arab visitors to the Suez Canal opening ceremony. It starts in the June 25, 1869 issue, p. 293, and ends in that of September 23, 1869, p. 686. At the same time, in June $1869 \mathrm{Abu}$ 'l-Su'ud announced that it would be published as an independent work as well. Reid provides its title as Wasf nukhbat al-athar al-qadima al-misriyya al-mawjūda fi khazinat al-tuhaf al-ilmiyya al-misriyya (Une visite au musée de Boulaq ou description des principaux monuments conservée dans les salles de cet établissement, [Paris: Frank, 1869]), as quoted in Donald Malcolm Reid, Whose Pharaohs? Archaeology, Museums, and Egyptian National Identity from Napoleon to World War I (Cairo: The American University of Cairo Press, 2002), 329 n. 35. However, in the many surviving copies of the separately printed catalogue the title is Furjat al-mutafarrij 'alā 'l-antīqah-khāna al-khadīwiyya al-kä'ina bi-Būlāq Mișr al-mahmiyya wa hiya 'ibārat 'an wașf nukhbat al-äthār al-qadìma al-mișriyya al-mawjūda fì khazinat al-tuhaf al-ilmiyya al-mișriyya (The Pleasure of the Spectator in the Khedival Museum in Bulaq in the Well-protected Lands of Egypt, which is the description of selected Egyptian antiquities in the Egyptian Cabinet of Scientific Curiosities) (Cairo: Mațba at Wādì al-Nìl, 1286 [1869-70; in the BnF, it is mistakenly dated on the covers and in the catalogue as 1862]). Some copies also have a French title page and a few introductory lines by Auguste Mariette (Une visite au musée de Boulaq ou description des principaux monuments conservée dans les salles de cet établissement), but otherwise contain the same Arabic translation (the French pages were bound with the Arabic text and published in Paris at A. Franck, 1869); perhaps this is the version to which Reid refers. Abu 'l-Su'ūd had already translated works on ancient Egyptian subjects in 1839 (under al-Tahtawi), and then also in 1864-65, at the order of the Khedive Isma il. According to Donald Malcolm Reid, the very title of his journal, $W \bar{a} d \bar{l}$ al-Nìl, reflects an Egyptian identity already imbued with the ancient history of the country: Reid, Whose Pharaohs?, 108-9. Reid does not mention that the catalogue was published in the $W \bar{a} d \bar{i}$ al-Nìl. More recently, Colla investigated the unique "Invocation of Abu 'l-Su'ud" in Furjat al-mutafarrij, which combines Muslim devotion and ancient Egyptian history. Elliott Colla, Conflicted Antiquities: Egyptology, Egyptomania, Egyptian Modernity (Durham, N.C.: Duke University Press, 2007), 127-29. Colla prefers the transliteration as
Furjat al-mutafarraj, which perhaps underlines that the Arab spectator is there "by chance," a "mere onlooker" (this is how Mawrid gives the meaning), but I am not sure whether Abu 'l-Su'ud meant it in this way, since Colla himself also emphasizes the translator's willingness to connect ancient Egypt with the (Muslim?) Egyptian reality of 1869. Abu 'l-Su'ud says that he translated the Description "with the intention to instruct the sons of Egypt and to call the attention of those who live today to the conditions of their noble forefathers," etc. This is why I preferred mutafarrij. I am grateful to Mercedes Volait for bringing Colla's work to my attention.

223. Mariette emphasizes "j’offre aux visiteurs indigènes du Musée un Catalogue écrit pour eux." Mariette, Une visite, n.p.

224. Wādì al-Nìl, July 2, 1869, 336. Colla notes that by this time athār had acquired "the technical meaning" of "antiquities" in Arabic. Colla, Conflicted Antiquities, 128. Yet, as we have seen, athär was in use much earlier in Ottoman Turkish in an artistic context. I have no data as to whether Abu 'l-Su' ud knew Ottoman Turkish, but it is likely that he was very much exposed to it, having served in the administration of the Egyptian pashas.

225. Wādì al-Nìl, September 23, 1869, 685.

226. Al-Ahrām, October 27, 1884.

227. Al-Ahräm, November 12 and 23, and December 1, 1886.

228. Al-Ahrām, May 22, 1891.

229. Aḥmad Afandī Fahmī, "Al-funūn al-jamīla," Al-Muqtațaf (February 1887): 260-65.

230. Ibid., 263-64.

231. Ibid., 264.

232. Ibid., 264-65.

233. Shaw, Ottoman Painting, 119-20. However, earlier Ottoman Turkish periodicals may contain such explanations.

234. Such as the Lebanese painters Kenaan Dib (d. 1873); Daoud Corm (d. 1930) (see Sarah Rogers, "Producing the Local: The Visual Arts in Beirut," MESA Bulletin 42, 1 and 2 [2008]: 19-25); Habib Srour (d. 1938); the famous Egyptian sculptor Mahmud Mukhtar (d. 1934); the Iraqi 'Abd al-Qadir al-Rassam (d. 1952); the Syrian Tawfiq al-Tariq (d. 1940?); and the Lebanese Ahmad Fahmi, etc.

235. To the best of my knowledge, Wijdan Ali is the only one to have surveyed art education in the late nineteenth and early twentieth centuries, but in this book the data is given according to the current political geography of (some) "Islamic countries," and without citing archival sources. Wijdan Ali, Modern Islamic Art, 9-11 (Ottoman Turkish soldier-painters), 35 (Lebanese Christian painters), 46 ('Abd al-Qadir al-Rassam, trained in Istanbul), 87 (Tawfiq al-Tariq, trained in Istanbul).

236. Shaw, Ottoman Painting, introduces Suleyman Seyyid and Ahmet Ali (pp. 60-66), Osman Hamdi (pp. 66-75), Ömer Adil (p. 89), Mehmed Vahit (p. 119), etc. 